\section{oril}

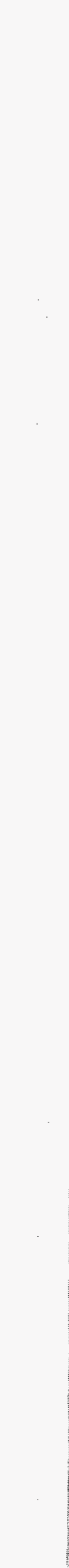

4t)

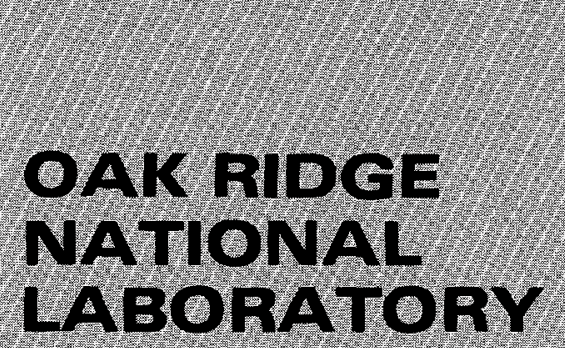

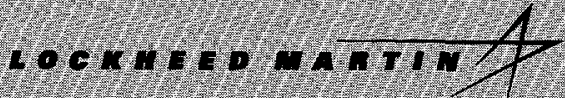
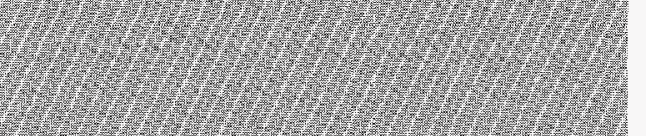

1)

te.t.

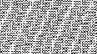

tro

trit

trat

(4)

tert

4.

1)

(1)

Why

aro

+1)

(1)

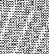

(1)

MANAGEDBY

LOCKHEED MARTIN ENERGY SYSTEUS, WNC

FOR THE UNITED STATES

DEPARTMENT OF ENERGY

\section{COMPENDIUM OF RECENT} BUILDING 7503 DATA
J. T. Shor 
This report has been reproduced directly from the best available copy.

Available to DOE and DOE contractors from the Ofrice of Scientific and Technical Information, P.O. Box 62, Oak Ridge, TN 37831; price available from (423) 576-8401.

Available to the public from the National Technical Information Service, U.S. Department of Commerce, 5285 Port Royal Rd., Springfield, VA 22161.

This report was prepared as an account of work sponsored by an agency of the U.S. government. Neither the U.S. government nor any agency thereof, nor any of their employees, makes any warranty, express or implied, or assumes any legal liability or responsibility for the accuracy, completeness, or usefulness of any information, apparatus, product or process disclosed, or represents that its use would not infringe privately owned rights. References herein to any specific commercial product, process, or service by trade name, trademark, manufacturer, or otherwise, does not necessarily constitute or imply its endorsement, recommendation, or favoring by the U.S. government or any agency thereof. The views and opinions of the author expressed herein do not necessarily state or reflect those of the U.S. government or any agency thereof. 
Chemical Technology Division

\title{
COMPENDIUM OF RECENT BUILDING 7503 DATA
}

\author{
Joel T. Shor
}

February 1996

Prepared by the

OAK RIDGE NATIONAL LABORATORY

Oak Ridge, Tennessee 37831

managed by

LOCKHEED MARTIN ENERGY RESEARCH CORP. for the

U.S. DEPARTMENT OF ENERGY

under contract DE-AC05-96OR22464 


\section{CONTENTS}

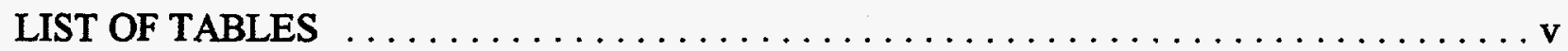

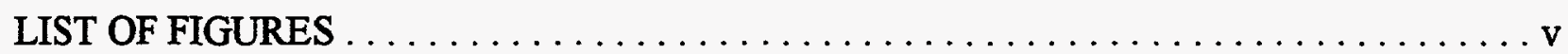

ACKNOWLEDGMENTS $\ldots \ldots \ldots \ldots \ldots \ldots \ldots \ldots \ldots \ldots \ldots \ldots \ldots \ldots \ldots \ldots \ldots \ldots$

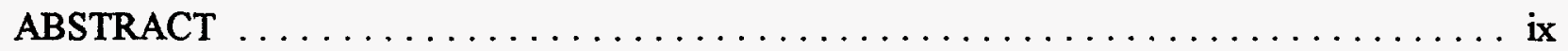

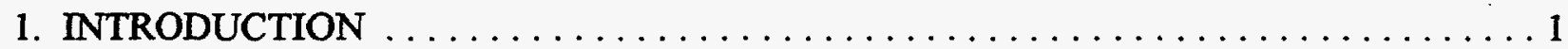

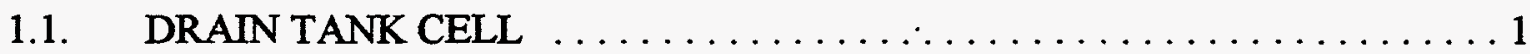

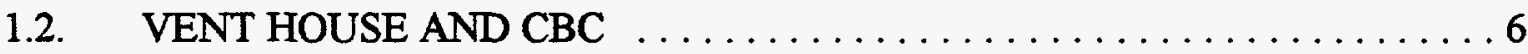

1.3. CELL PRESSURES AND SUMP LEVELS $\ldots \ldots \ldots \ldots \ldots \ldots \ldots \ldots \ldots$

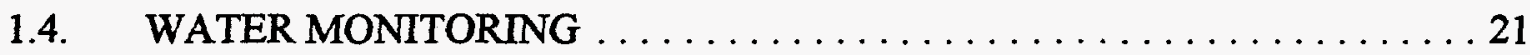

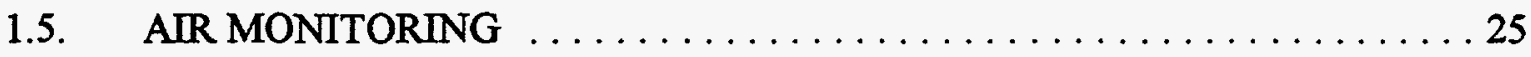

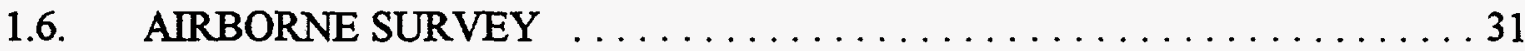

1.7. GAS SAMPLING OF PROCESS PIPING $\ldots \ldots \ldots \ldots \ldots \ldots \ldots \ldots \ldots$

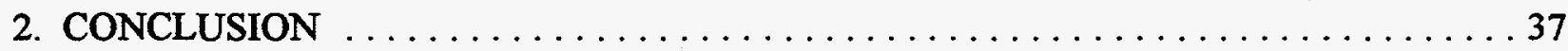

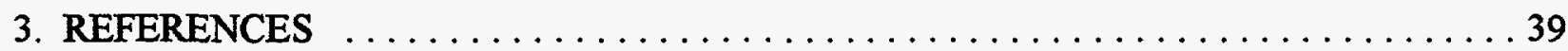

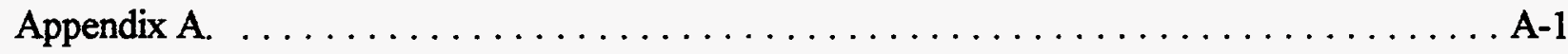

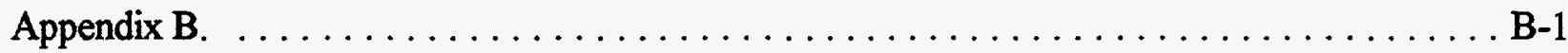




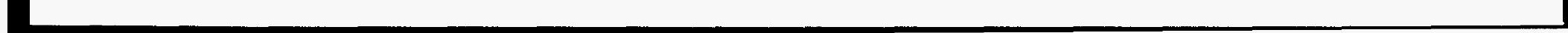




\section{LIST OF TABLES}

Number

Page

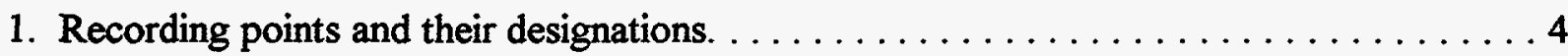

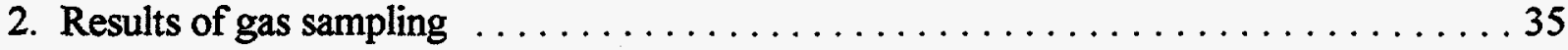

\section{LIST OF FIGURES}

Number

Page

1. Plan view of the MSRE basement floor $\ldots \ldots \ldots \ldots \ldots \ldots \ldots \ldots \ldots \ldots \ldots$

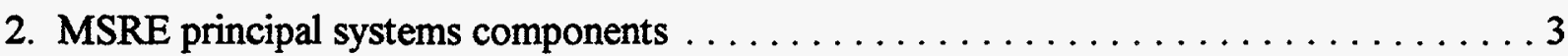

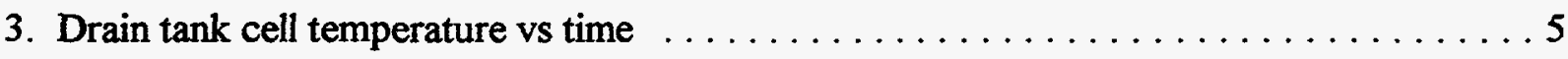

4. Fuel drain tank 1 , temperature $\left({ }^{\circ} \mathrm{F}\right) \ldots \ldots \ldots \ldots \ldots \ldots \ldots \ldots \ldots \ldots$

5. FD1 1993 temperatures $\left({ }^{\circ} \mathrm{F}\right) \ldots \ldots \ldots \ldots \ldots \ldots \ldots \ldots \ldots \ldots \ldots \ldots \ldots$

6. Thermocouples: positions in fuel drain tanks $\ldots \ldots \ldots \ldots \ldots \ldots \ldots \ldots$

7. MSRE core heat generation vs time, actinides and fission products $\ldots \ldots \ldots \ldots$

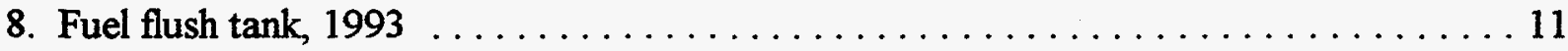

9. Auxiliary charcoal bed inlet temperatures vs time $\ldots \ldots \ldots \ldots \ldots \ldots \ldots \ldots$

10. ACB 1-1 thermocouple position in ACB cell $\ldots \ldots \ldots \ldots \ldots \ldots \ldots \ldots$

11. Pressure in vent house piping vs time (gage PT518) $\ldots \ldots \ldots \ldots \ldots \ldots \ldots \ldots$

12. Pressure vs time 1995 , PT518 . . . . . . . . . . . . . . . . . . 16

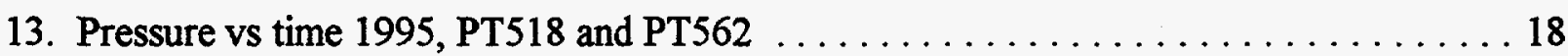

14. Vent house piping, pressure difference between

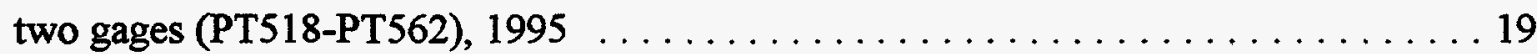

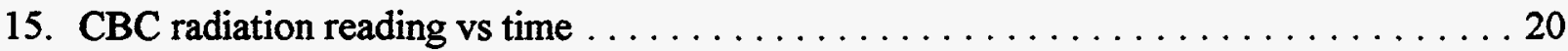

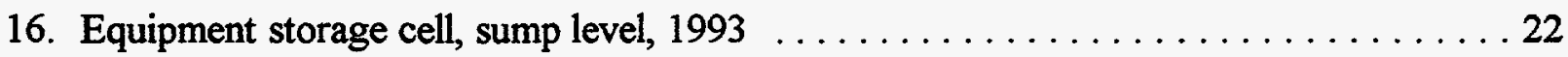

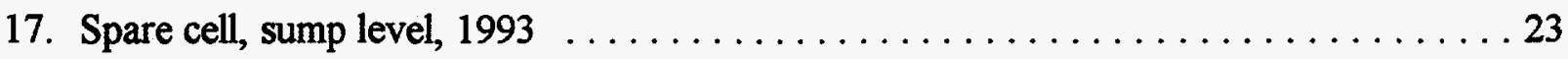

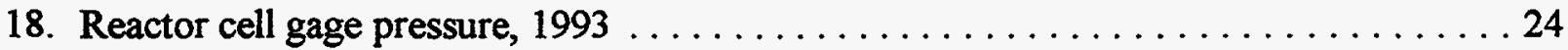

19. Locations of ground water monitoring wells

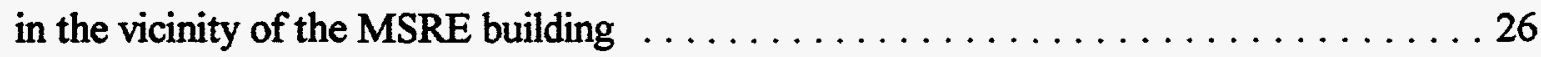

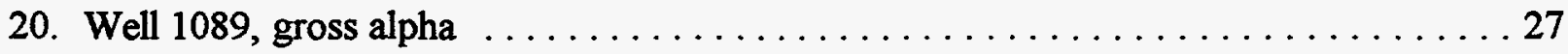

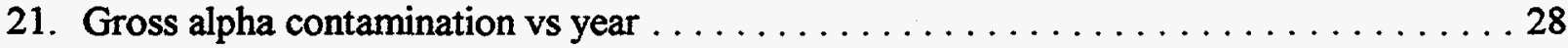

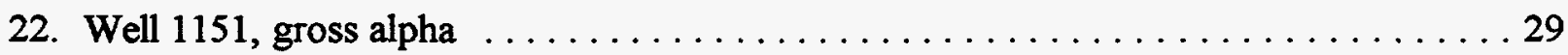

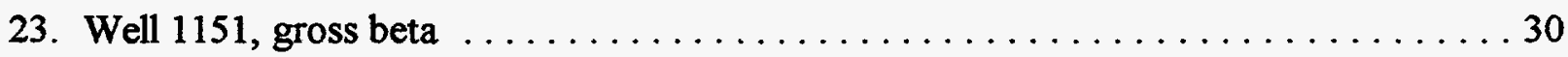

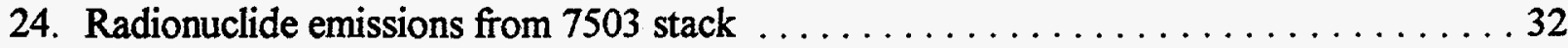


25. Gross count rate contour map for man-made

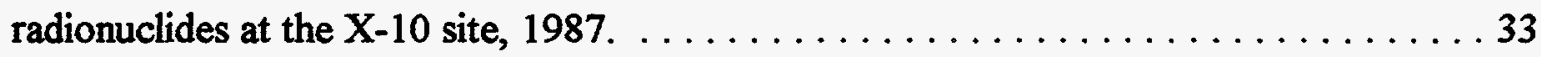

26. Gross count rate contour map for man-made radionuclides at the X-10 site, 1992

Appendix A.

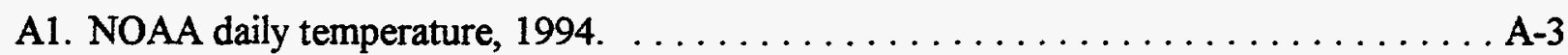

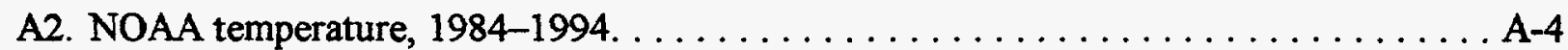

A3. Daily average temperatures recorded at steam plant, $1994 \ldots \ldots \ldots \ldots \ldots \ldots$ A-5

Appendix B.

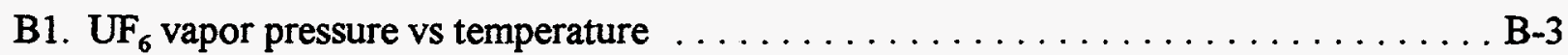

B2. Scatter diagram, PT518, pressure vs drain tank cell temperature, $1994 \ldots \ldots \ldots \ldots$ B-8 


\section{ACKNOWLEDGMENTS}

This document does not reference all the persons who aided in its preparation. Special thanks are owed to Mark Easton, Mark Ford, Gary Mays, Steve Burman, Ruth Ann Abston, Dick Engel, and many others. Fred Peretz and Suman Singh guided its development, and Nancy Smith more than typed it; she prepared it from a very rough copy. 


\title{
COMPENDIUM OF RECENT BUILDING 7503 DATA
}

\author{
Joel T. Shor
}

\begin{abstract}
This report is a compendium of available temperature, pressure, radiation, and other data from Building 7503, pertinent to the Molten Salt Reactor Experiment (MSRE) Remediation Project. The information is divided into sections that correspond to different components, cells, or areas of the defunct MSRE. A certain amount of data is included on groundwater monitoring wells around the building and on stack radionuclide emissions. As far as possible, information is provided on the methods by which the data were collected and on their interpretation. It can be concluded from this study that no evidence exists of a spread of air or water contamination. However, certain variations and data trends of the pressures in MSRE piping lack complete explanations at present.
\end{abstract}





\section{INTRODUCTION}

A plan view of the basement floor of Molten Salt Reactor Experiment (MSRE) building (Bldg. 7503) is shown in Fig. 1. Figure 2 shows a schematic of some of the important piping and several of the instrument locations. Data are available from (a) a 21-point recorder located in the main building which connects instruments building wide, and (b) a 12-point recorder in the vent house which connects to instruments in the charcoal bed cell (CBC). The recording points and their designations are shown in Table 1.

The largest portion of available data pertains to the drain tank cell and its components. The spent fuel from the last reactor operation is stored in two tanks within this cell. Fairly extensive data are available on some parameters from the CBC. Data exist on the sump liquid level in almost every cell of the building. The building stack contains real-time alpha and beta/gamma monitors capable of collecting data as gas flows past the sensors. In addition, cumulative stack data have been taken since 1992. Data in general are sporadic. For example, data for certain years and days are missing, and some of the data are suspect in nature.

\subsection{DRAIN TANK CELL}

The fuel drain tank cell temperature indicated by TE-DTC-1 is recorded on element 10 of the formerly operating 30-point Yokogawa ${ }^{\mathrm{TM}}$ recorder located in the heater control room in the basement of Bldg. 7503. The thermocouples for this instrument are type $\mathrm{K}$; these are nickel chromium alloy-nickel aluminum alloy that have a range from -250 to $1260^{\circ} \mathrm{C}$ and generally have an accuracy of $\pm 2.2^{\circ} \mathrm{C}$. $^{1}$ These thermocouples are not greatly subject to neutron damage. ${ }^{2}$ Data are available from 1984 through early 1995 (except for 1991). The tanks were heated (annealed) approximately annually until 1991, to effect the recombination of radiolyzed salt. The months in which this operation was performed are indicated by arrows in Fig. 3.

The high points in the figure appear to follow the annual heating-provided heating was done during the hotter months of the year. For example, in 1990 when the operation was performed in January, there is scarcely any peak in the data, while in 1985 when the annealing was done in June and in 1986 when it was performed in September, there are more pronounced peaks. 


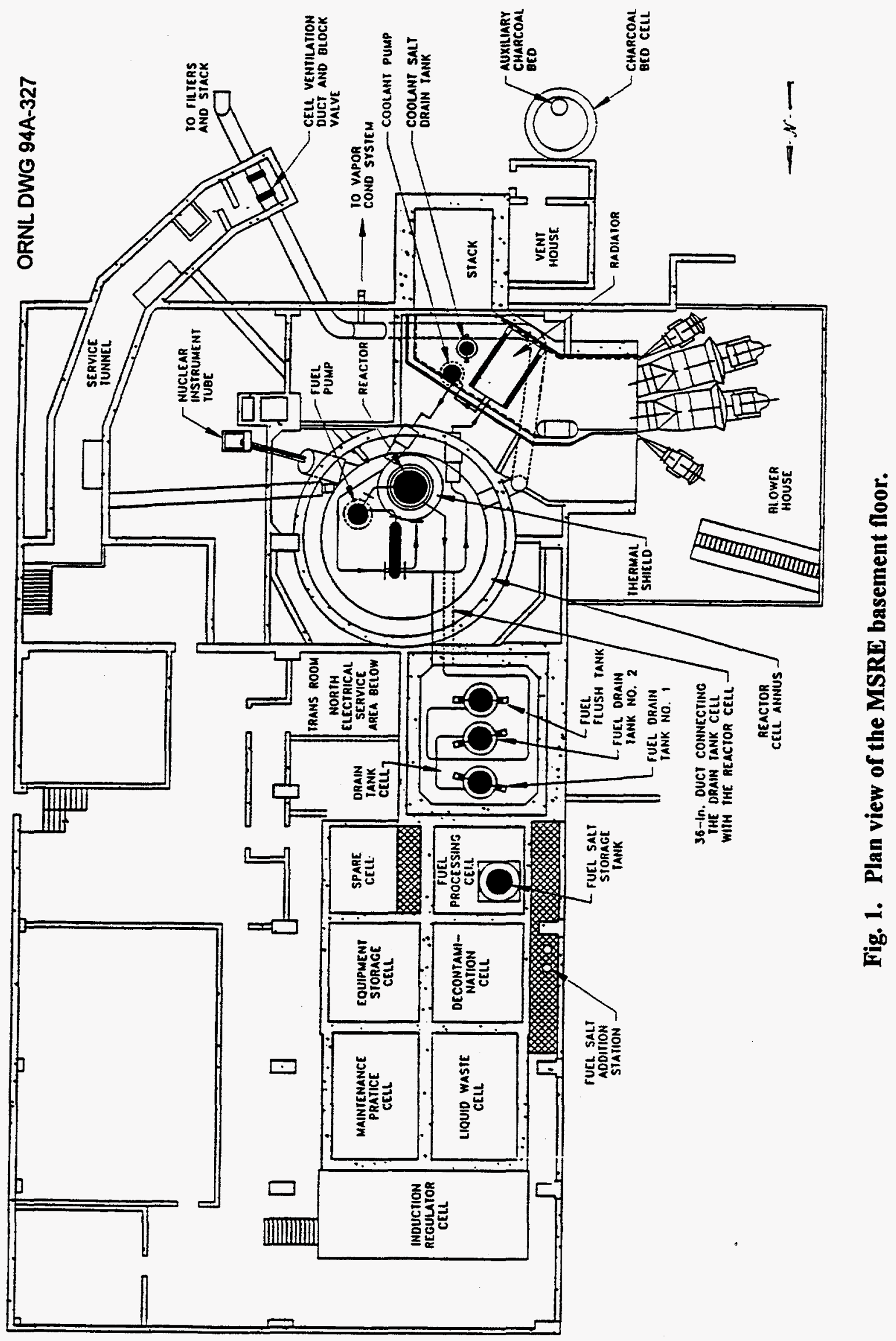




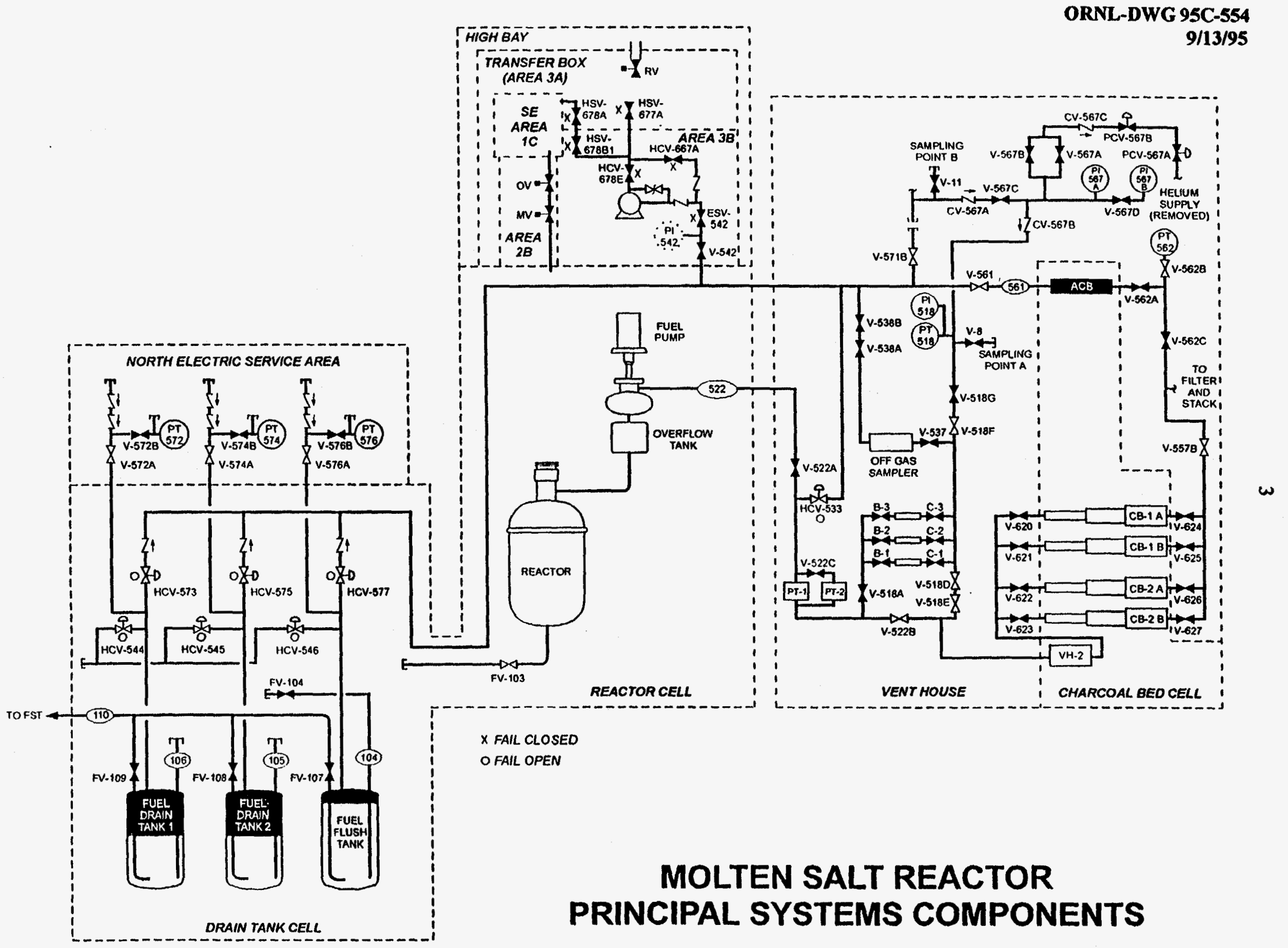

Fig. 2. MSRE principal systems components. 
Table 1. Recording points and their designations.

\begin{tabular}{|c|c|}
\hline Indicator & Description \\
\hline 1. TE-FD1-19A & Salt in fuel drain tank (FDT)1 \\
\hline 2. TE-FD1-5 & FDT1 bottom \\
\hline 3. TE-FD1-15 & FDT1 side \\
\hline 4. FD1-19A & Salt in FD1 \\
\hline 5. TE-FD2-5 & FDT2 bottom \\
\hline 6. TE-FD2-15 & FDT2 side \\
\hline 7. TE-FFT-4 & Fuel flush tank (FTT) bottom \\
\hline 8. TE-FFT-11 & FFT midplane \\
\hline 9. TE-FFT-7A & FFT top \\
\hline 10. TE-DTC-1 & Drain tank cell \\
\hline 11. PT562 & Vent house piping pressure \\
\hline 12. LE-RC-C & Reactor cell, sump level \\
\hline 13. LE-DTC-A & Drain tank cell, sump level \\
\hline 14. LE-FSC & Fuel process cell, sump level \\
\hline 15. LE-TC & Spare cell, sump level \\
\hline 16. LE-SC & Equipment storage cell \\
\hline 17. LE-WTC & Liquid waste cell \\
\hline 18. PT-GS & Gas supply pressure \\
\hline 19. PT-RC-A & Reactor cell pressure \\
\hline 20. None & Spare \\
\hline 24. PT518 & Vent house piping pressure before $A C B$ \\
\hline 28. LS-PRS-A & Pump room sump level \\
\hline 29. RE-S1-A & Stack alpha activity \\
\hline 30. RE-S1-B & Stack beta/gamma activity \\
\hline
\end{tabular}




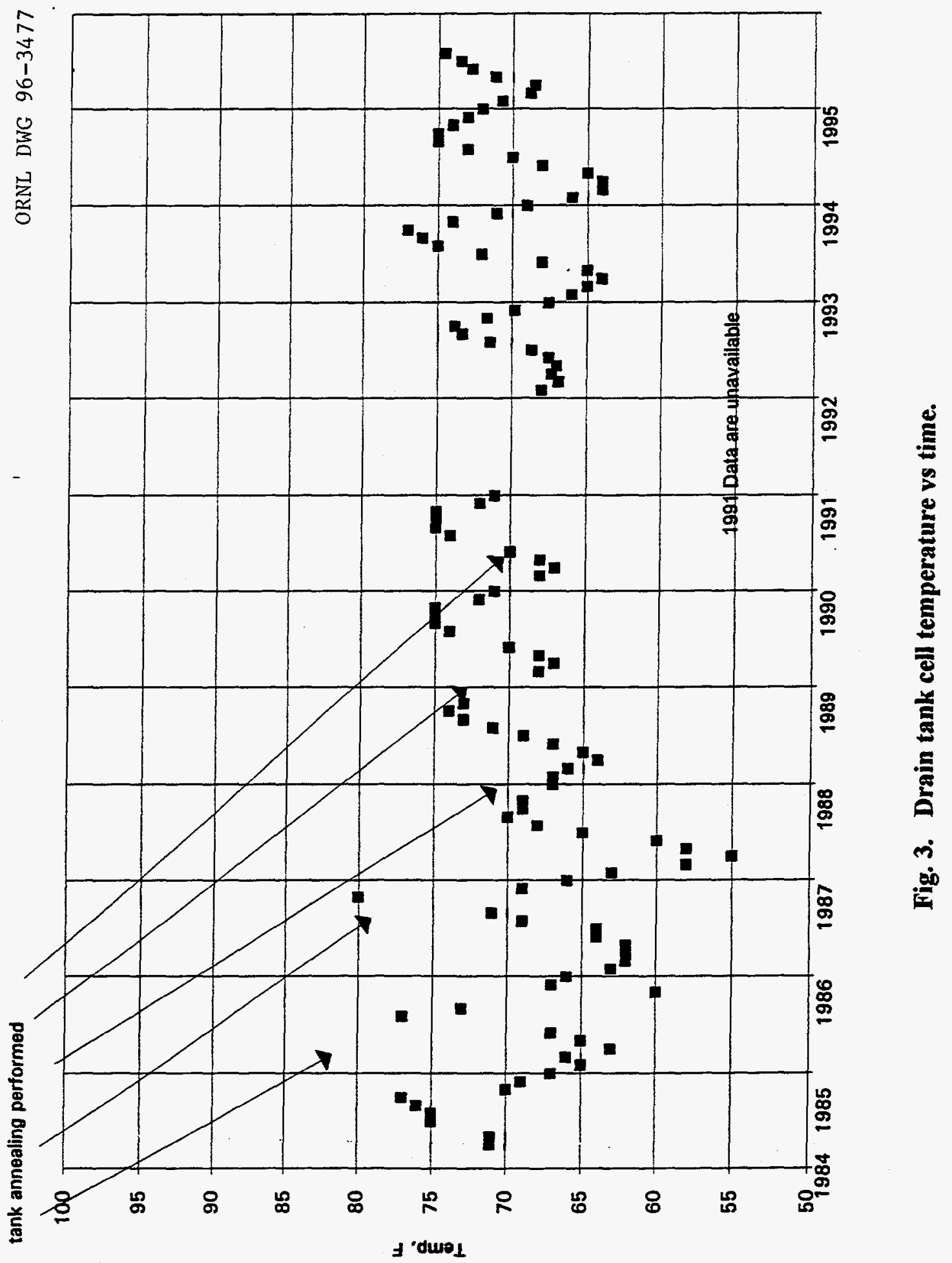


It is unclear why the cell temperature dropped to a low value in 1987. A comparison of cell temperatures with average daily outdoor temperaturesprovided by the National Oceanic and Atmospheric Administration (NOAA), ${ }^{3}$ shown in Appendix A, does not seem to suggest an apparent reason. The salt temperature data are indicated by the temperature element TE-FD1-19A located in fuel drain tank No. 1 (FD1). The annual variation of this temperature follows a similar pattern, as shown in Fig. 4, except for the low-temperature spike found in 1987. The probe is located in a thermocouple bayonet (pipe with closed end) 64 in. from the top of the bowl of the 86-in. high tank.

In Fig. 5, we have the monthly temperatures plotted for several different points in FD1 during 1993. The temperature variation is representative of its behavior in other years. The approximate positions of the thermocouples in the fuel drain tank are shown in Fig. 6. From Fig. 5 it can be seen that the bottom-element temperature, TE-FD1-5 (measured on the side of the bottom bowl of the tank) and the side temperature, TE-FD1-15 (measured on the side of the cylindrical portion of the tank's exterior 72 in. from the top), follow each other very closely and in fact, very often overlap; however, the salt temperature, FD1-19A measured inside the tank, as shown in Fig. 3 , is consistently hotter by about 4 or $5^{\circ} \mathrm{F}$. This may be due to the heat produced by the disintegration of the actinides and fission products remaining in the fuel. The heat produced in the reactor (based on ORIGEN2 calculations) since its shutdown 25 years ago is shown in Fig. 7 and appears to be asymptomatically approaching $100 \mathrm{~W} .{ }^{4}$ A comparison of the temperatures of the fuel drain tank salts can be made with that of the fuel flush tank, which is low in fuel concentration because it contains salt that was used only to flush the system after shutdown and was never loaded with uranium tetrafluoride. Figure 8 is a plot of the temperatures of the tank bottom and midsection in the fuel flush tank in 1993, a representative year. It can be seen that the temperatures fall about $5^{\circ} \mathrm{F}$ lower than the salt temperature data shown in Fig. 5 and follow a similar annual cycle. The temperatures recorded by FD2 follow almost exactly those of FDl and are not shown.

\subsection{VENT HOUSE AND CBC}

The vent house and CBC cells are treated together because they are adjacent and because available data of the two areas are closely connected. The vent house contains particle traps 


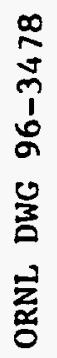

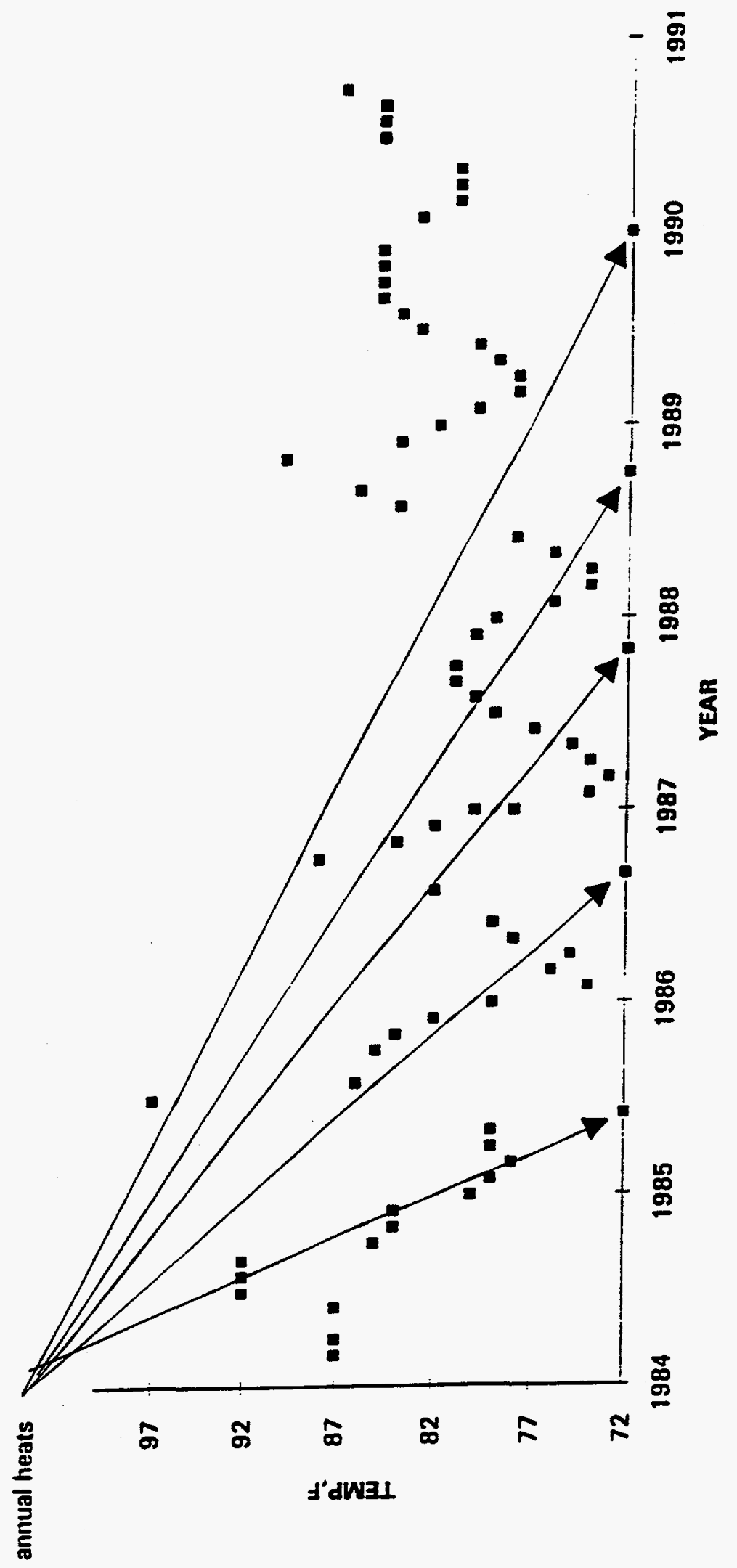

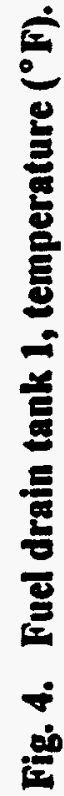




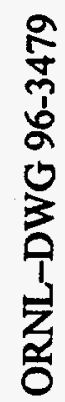

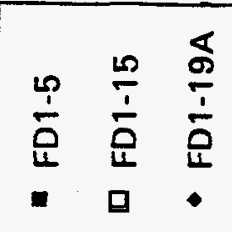

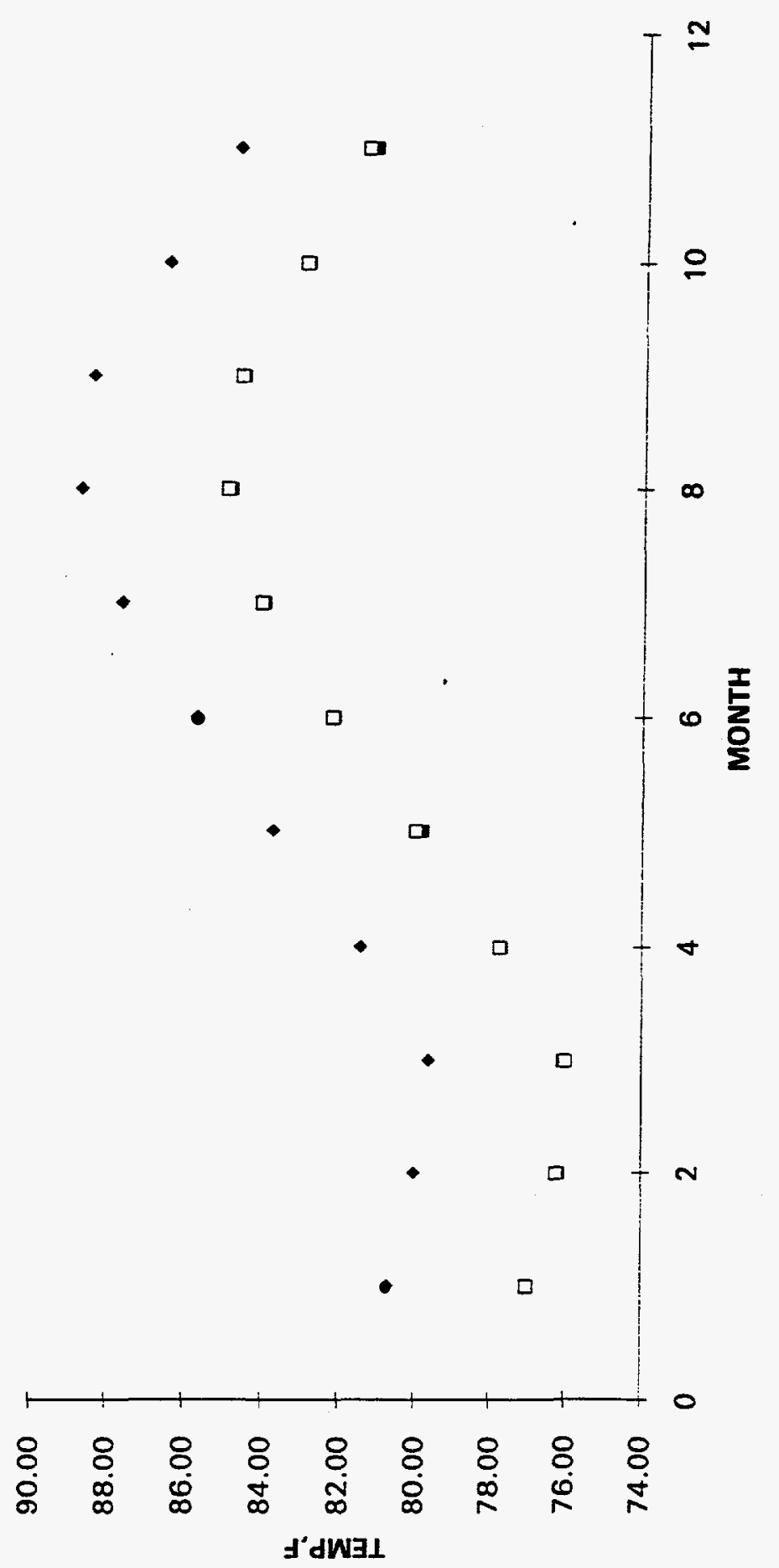

家 


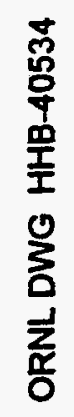

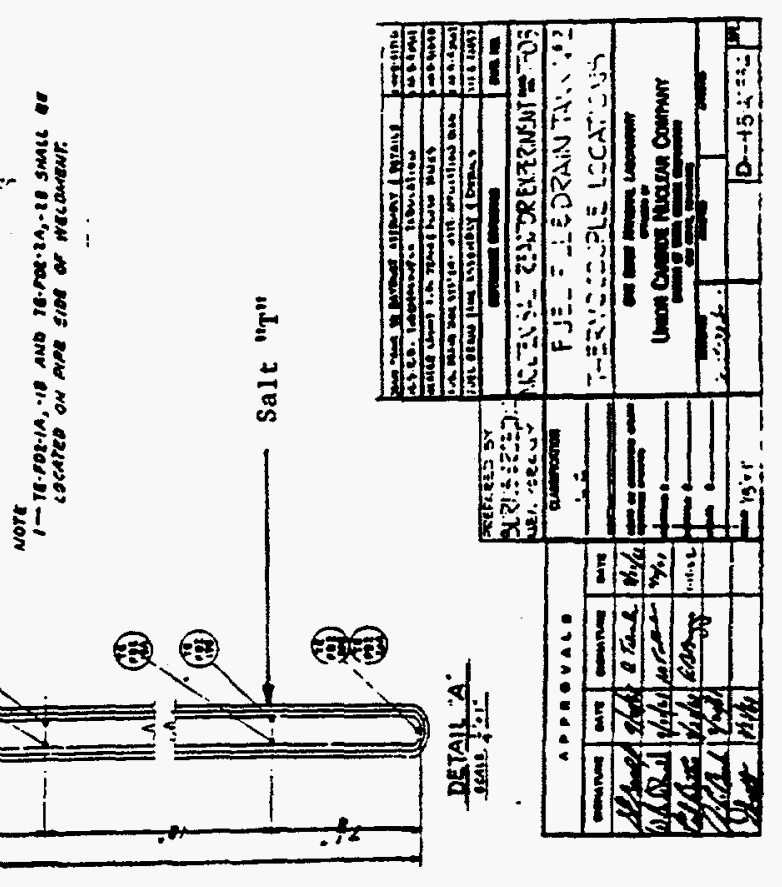

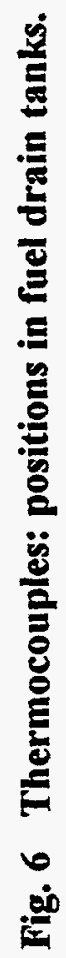
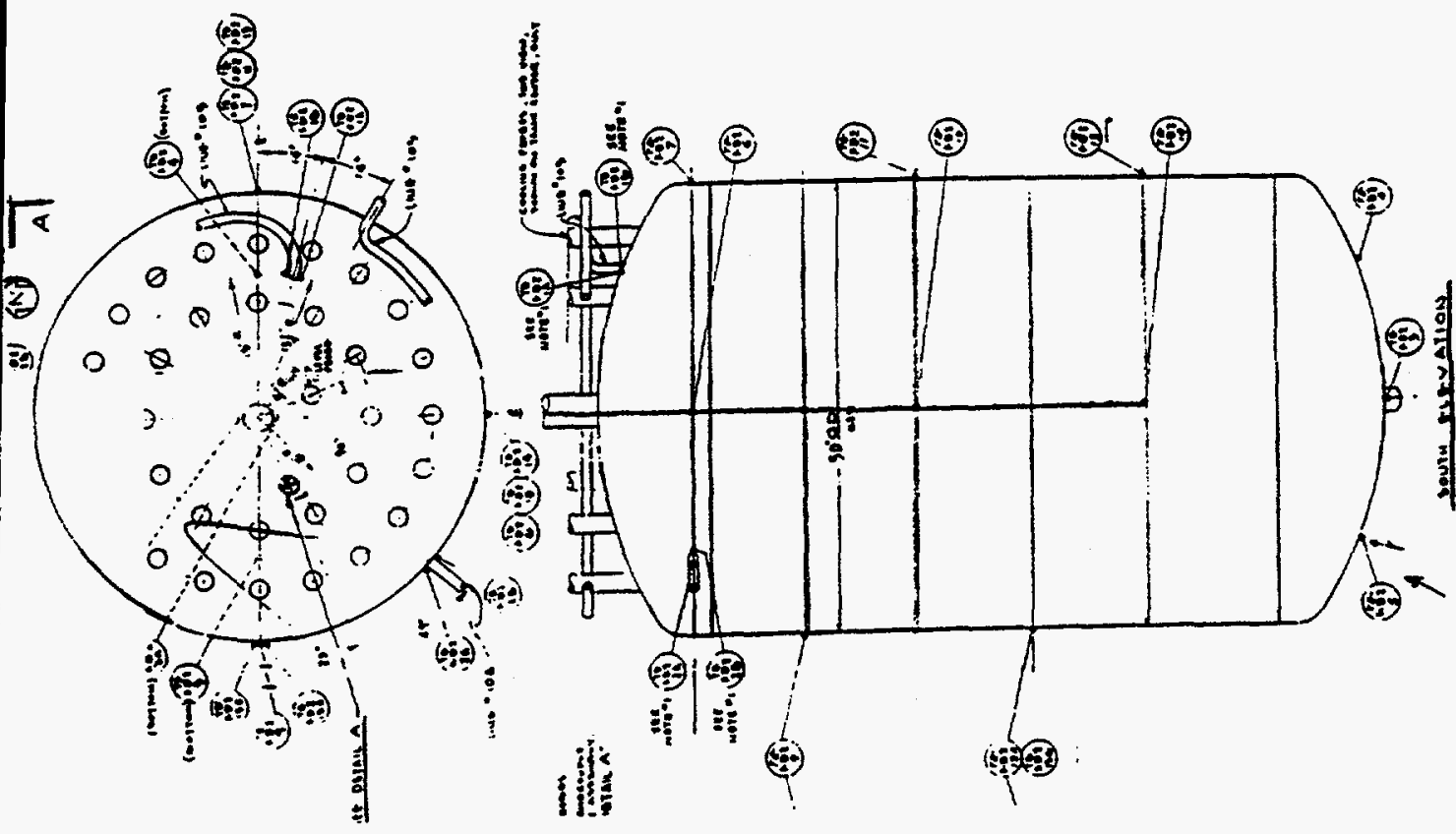

옹 


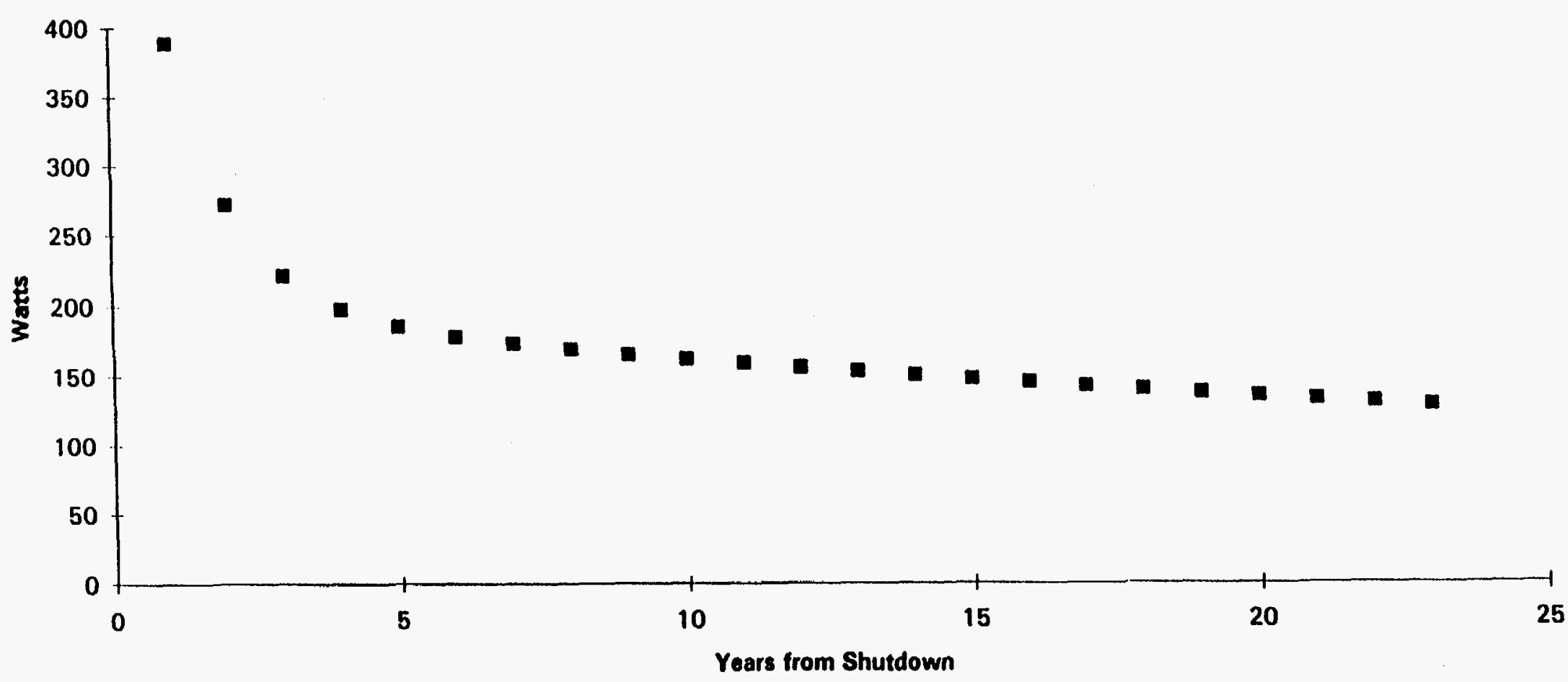

Fig. 7. MSRE core heat generation vs time, actinides and fission products. 


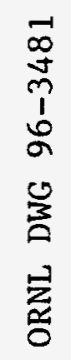

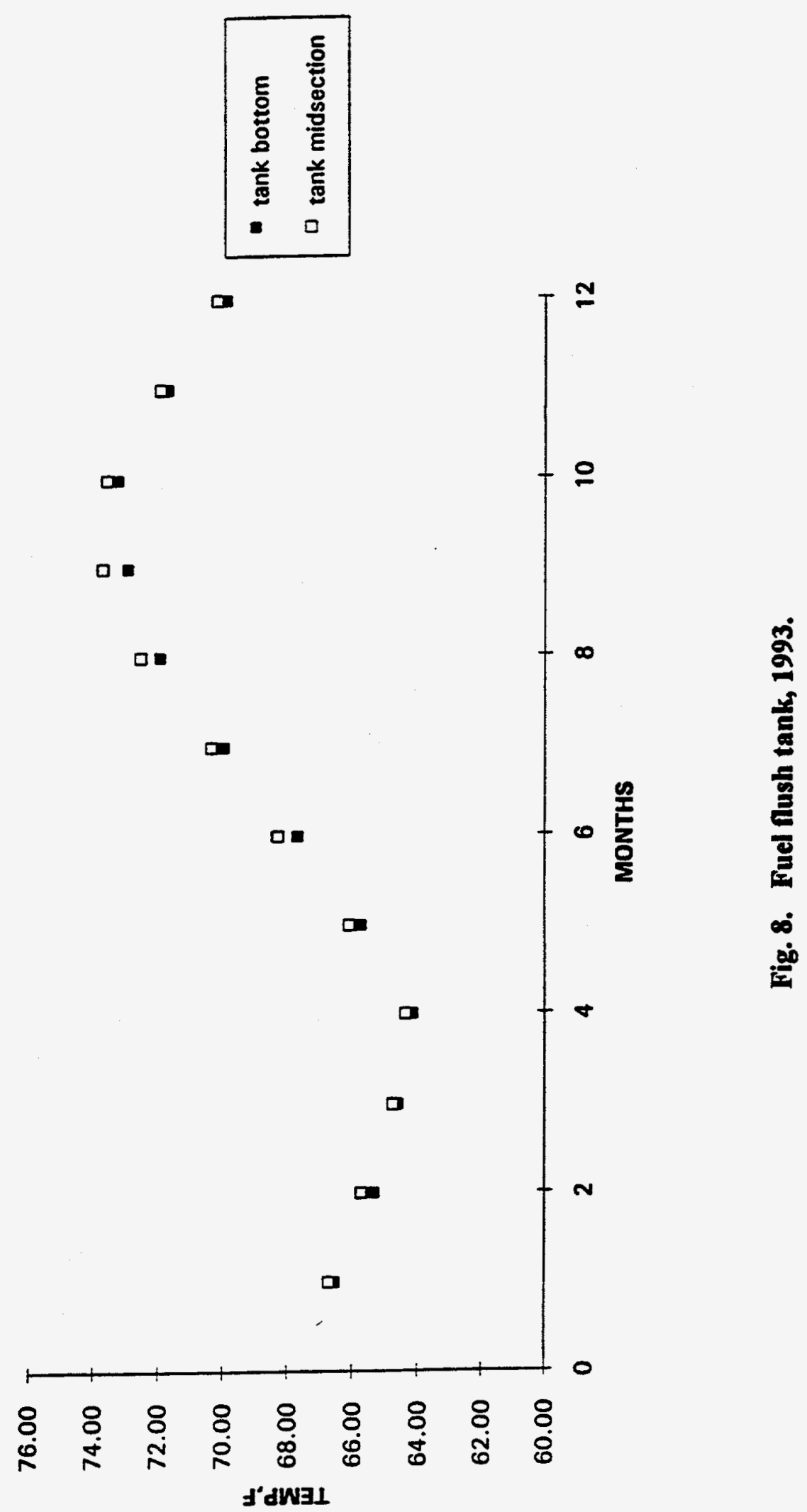


labeled PT-1 and PT-2 as shown in Fig. 2, and gas-sampling devices; the CBC contains charcoal beds used to sorb radioactive off-gases. Between July and November 1994, the CBC was drained of water to bring it to a level of $2 \mathrm{ft}$ to reduce the risk of a criticality occurring from the sorbed uranium hexafluoride $\left(\mathrm{UF}_{6}\right)$ on the charcoal trap. Temperatures along the centerline of the CBC were recorded above and below the water levels, and limited data are available. The temperatures at the inlet to the auxiliary charcoal bed (ACB), ACB1-1, are shown in Fig. 9 from July 1994 to August 1995 (inclusive) along with several important events in the history of the CBC for the year. Data are missing from November and December 1994, immediately following the completion of cell draining. The data show an increased scatter at this point, possibly owing to the absence of the thermal inertia of the water contained in the cell prior to that time. The position of thermocouple ACB1-1 is shown in Fig. 10. It is at an elevation of $844 \mathrm{ft}$ (above sealevel) at the top of the column. Data are available on the pressure in the vent house piping from gage PT518, a Foxboro ${ }^{\mathrm{TM}} 841$ GM-AIl pressure transducer with a stainless steel diaphragm and a wheatstone bridge strain gage, with a calibrated range of -2.5 to $+5 \mathrm{psig}$. The gage has been in place since 1991, and recalibration has not been performed to date. ${ }^{5}$ Its reading in pounds per square inch gage (referenced to a constant $760 \mathrm{~mm} \mathrm{Hg}$ atmospheric pressure) vs time is shown in Fig. 11, (518, psig, 1990-1995) along with important events during the past 5.5 years. Gage PT518 indicates a slow but definite rise in pressure since early 1994, a rise tempered by seasonal variations in temperature. Gas generation inside the piping owing to radiolysis of the fuel and flush salts, or chemical reactions which produce additional gas are hypothesized to be possible causes. The radiolytic gas generation hypothesis is suggested by the observation that an induction period of approximately 4 years has elapsed since the most recent annealing of the salt. Based on information from Green, ${ }^{6}$ an approximate 5-year induction time was expected, near that observed here. The pressure cycles secondarily with the seasons also. Figure 12 is a plot of the pressure gage reading (PT518) on the inlet of the auxiliary charcoal bed, acquired daily during 1995. Near the beginning of August it was observed that the pressure began a rapid decline from a maximum of 2 psig, a decline also reflected in the readings of gage PT562 [Precision Instruments Model $4318,0-800$ torr, calibrated range ( 0 to $15.5 \mathrm{psig}$ )] on the outlet of the $A B C$. The pressure 


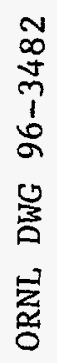

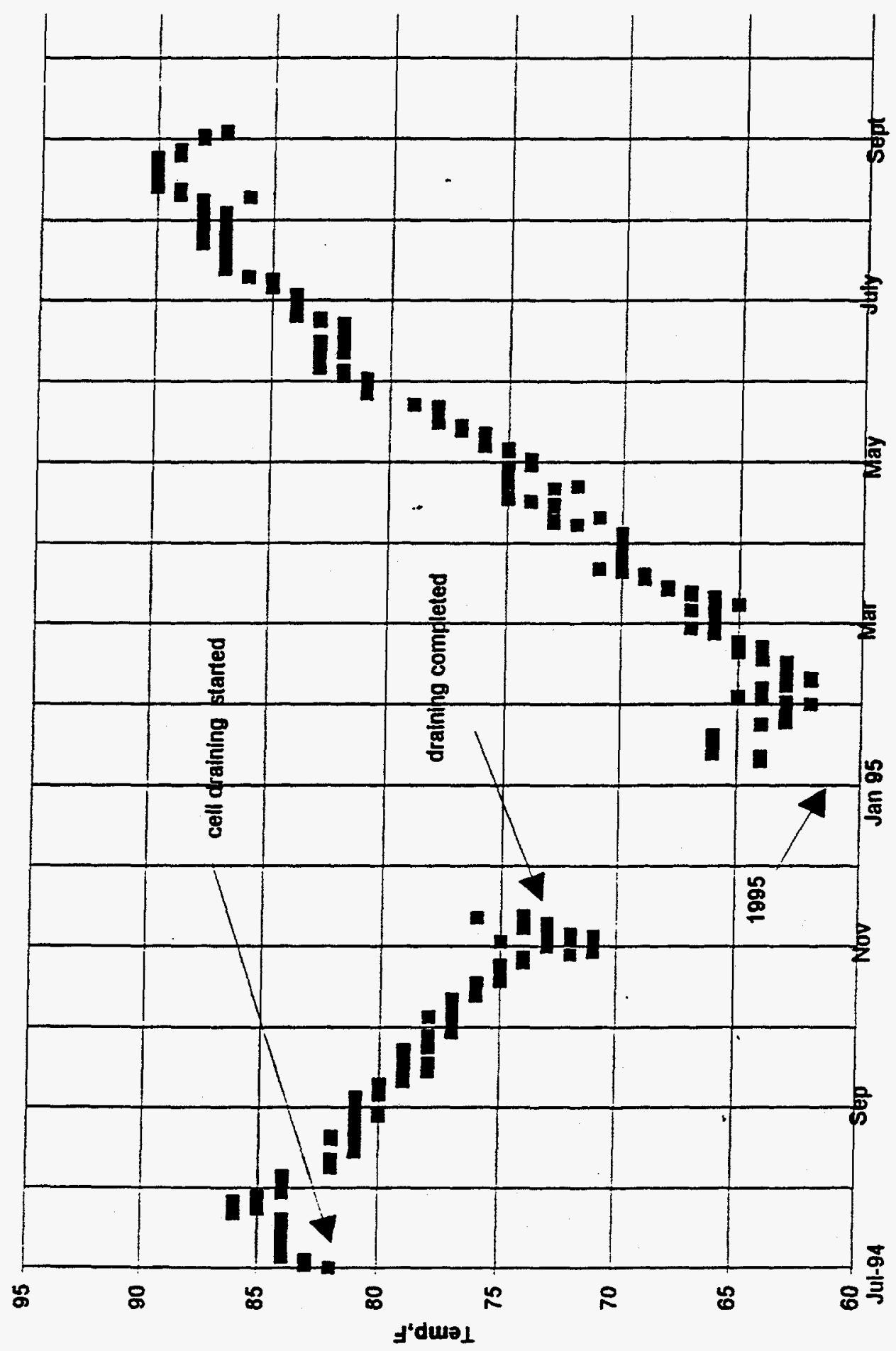

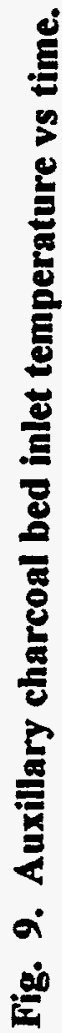




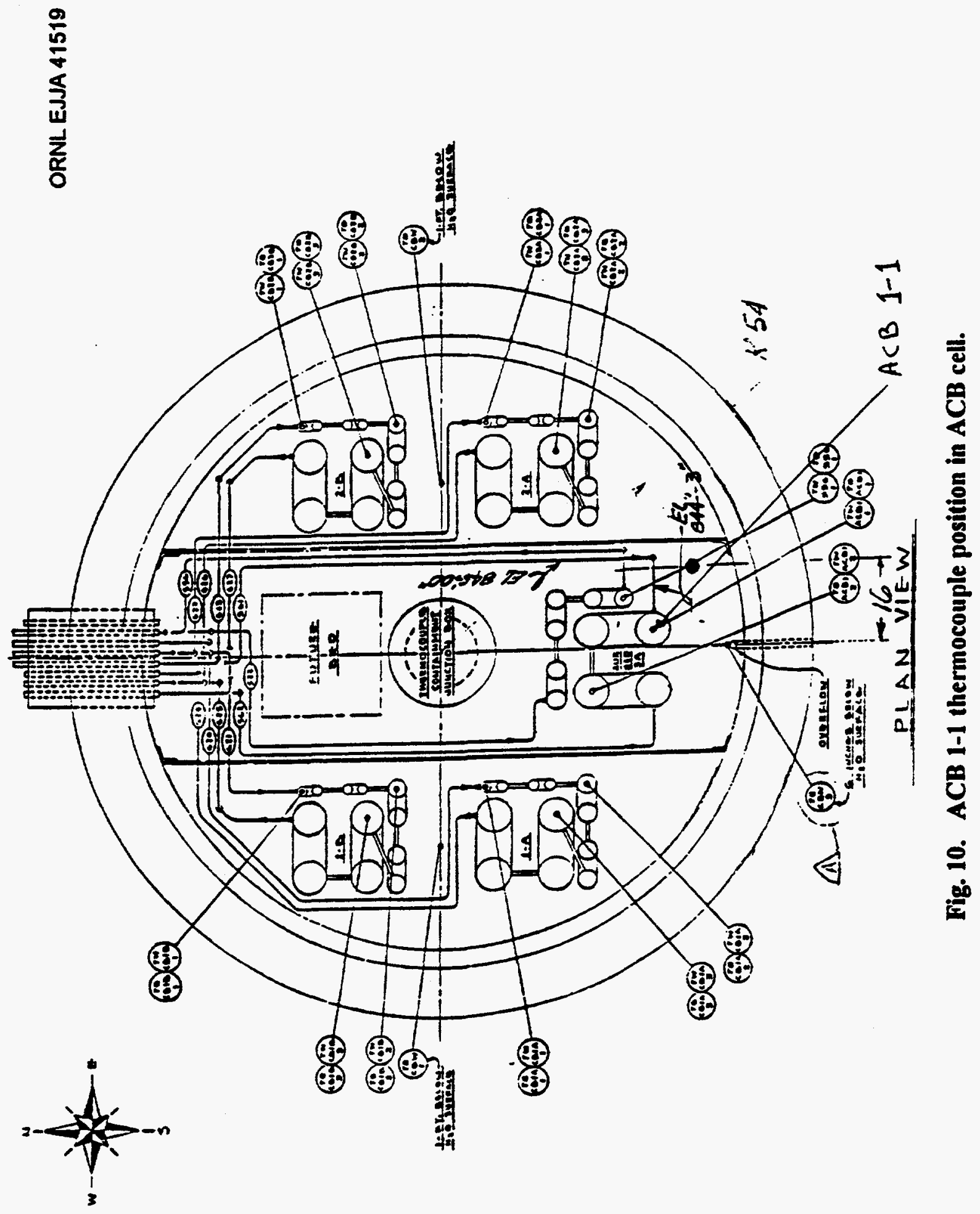




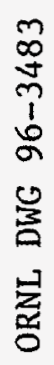

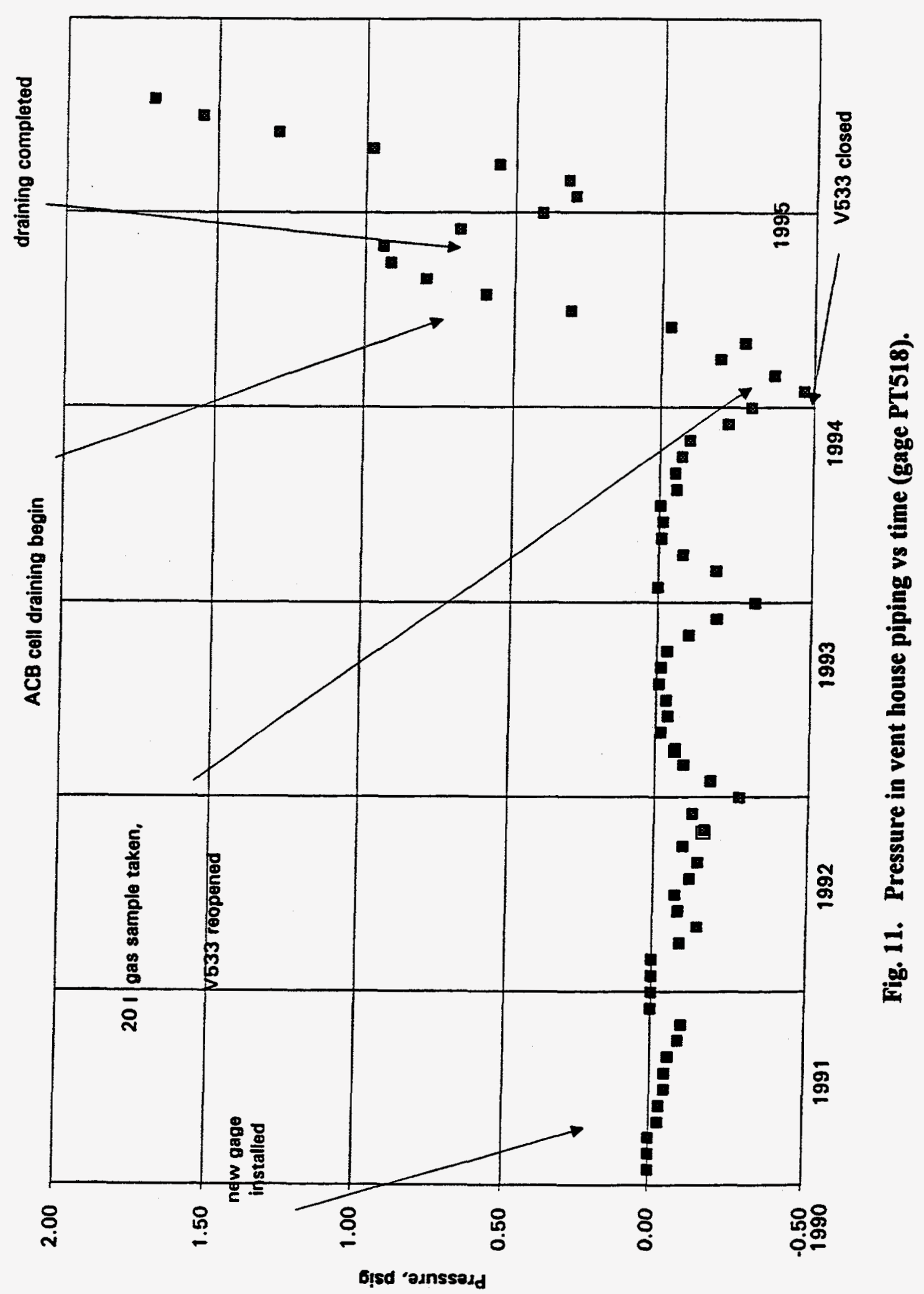




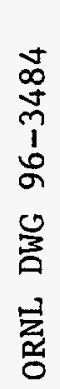

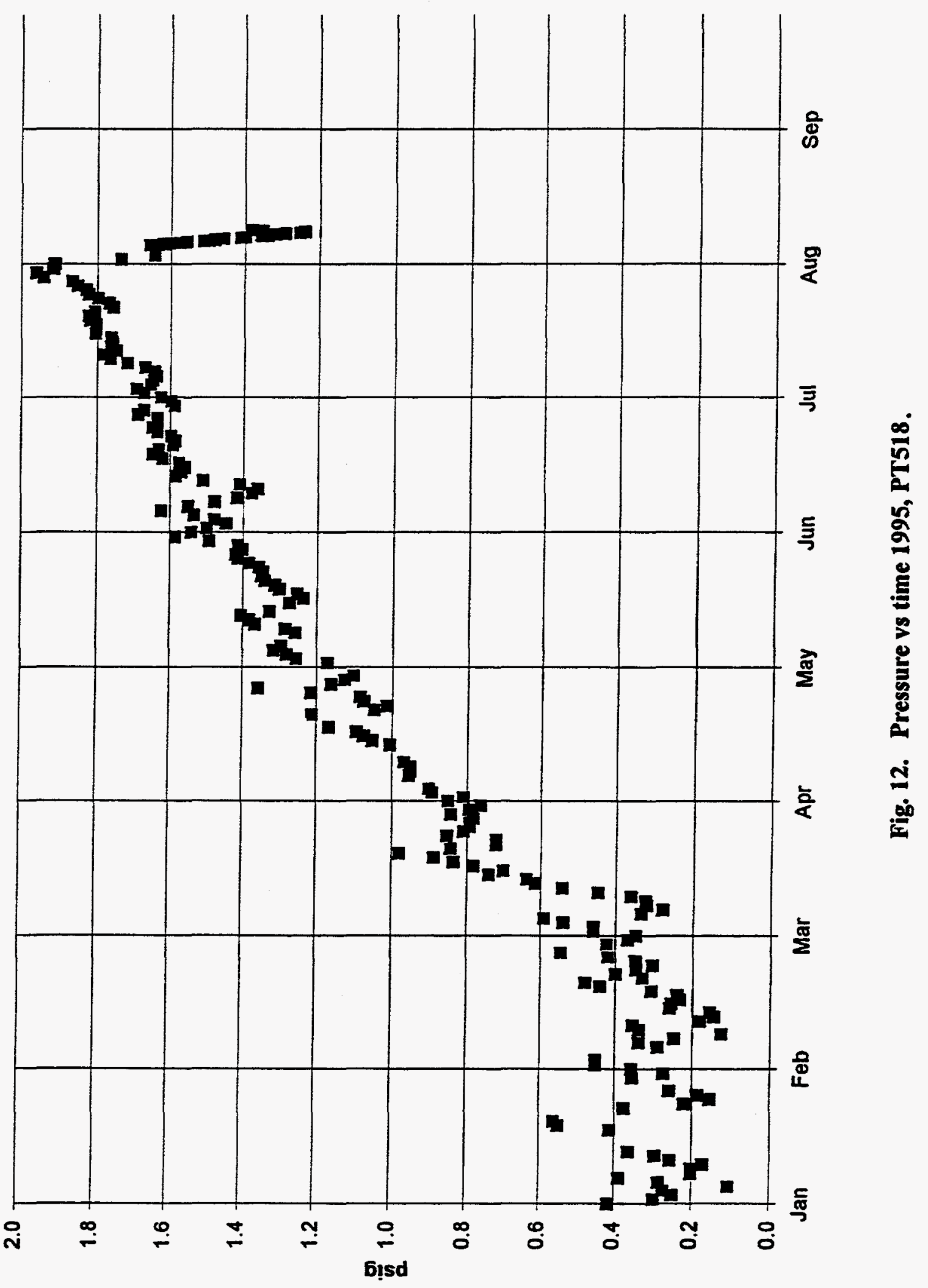


decline is believed to be caused by to the opening (and failure to reseat) of a check valve (not shown on the drawing) upstream of V562C. There was an interesting "blip" in the declining pressure which occurred on August 14 (Fig. 13), and could not be related to a comparable change in temperature of the vent house, barometric pressure, or any particular activity in the area. The blip remains unexplained at this time.

In March 1994, a 1-L sample of the gas in the vent house piping was taken, and valve $\mathrm{V} 518 \mathrm{G}$ was closed. The closing of this valve would diminish the volume of gas that would have contacted PT518. Later pressure testing suggested that this valve was leaking. ${ }^{7}$ An analysis of the volume of piping and the pressure which would develop under the assumption that $\mathrm{UF}_{6}$ is present in the solid phase is shown in Appendix B. Also shown in Appendix B is a graph of $\mathrm{UF}_{6}$ vapor pressure vs temperature based on data from HSC Outokompu Research. ${ }^{8}$ The presence of $\mathrm{UF}_{6}$ solid in equilibrium with its gas could produce dramatic rises in pressure with relatively minor changes in temperature. It is also possible that the piping between the vent house and the drain tank cell became plugged with solid $\mathrm{UF}_{6}$ (and other contamination) during the winter months when portions of the line were exposed to the ambient outdoor temperatures. Pressure gage PT562, also located in the vent house, appears to follow fairly closely the pressure of PT518, but it reads consistently less, as can be observed in Fig. 14, for pressures measured during the first half of 1995. Whether the absolute measurements of either gage are accurate is not known. Data were recorded using a Bicron ${ }^{\mathrm{TM}}$ RSO-5,50,500 beta-gamma ionization chamber survey meter through a 4-in. penetration in the $\mathrm{CBC}$ concrete shield plug from November 1994 until the present. ${ }^{9}$ After V562C was found to leak, it was replaced with a new valve. At the same time a calibrated pressure transducer with an appropriate range was installed in place of the earlier PT562. Following these activities, PT518 and the new PT562 were found to track to within 0.06 psi of each other, and after a day or two, they tended to track within 0.02 psi of each other. They are shown normalized with respect to the initial radiation reading and with respect to time in Fig. 15. The accuracy of the survey meter, as advertised by the manufacturer, is $\pm 5 \%$. The readings suffered from an inconsistency in the position of the ionization detector that was used to measure 


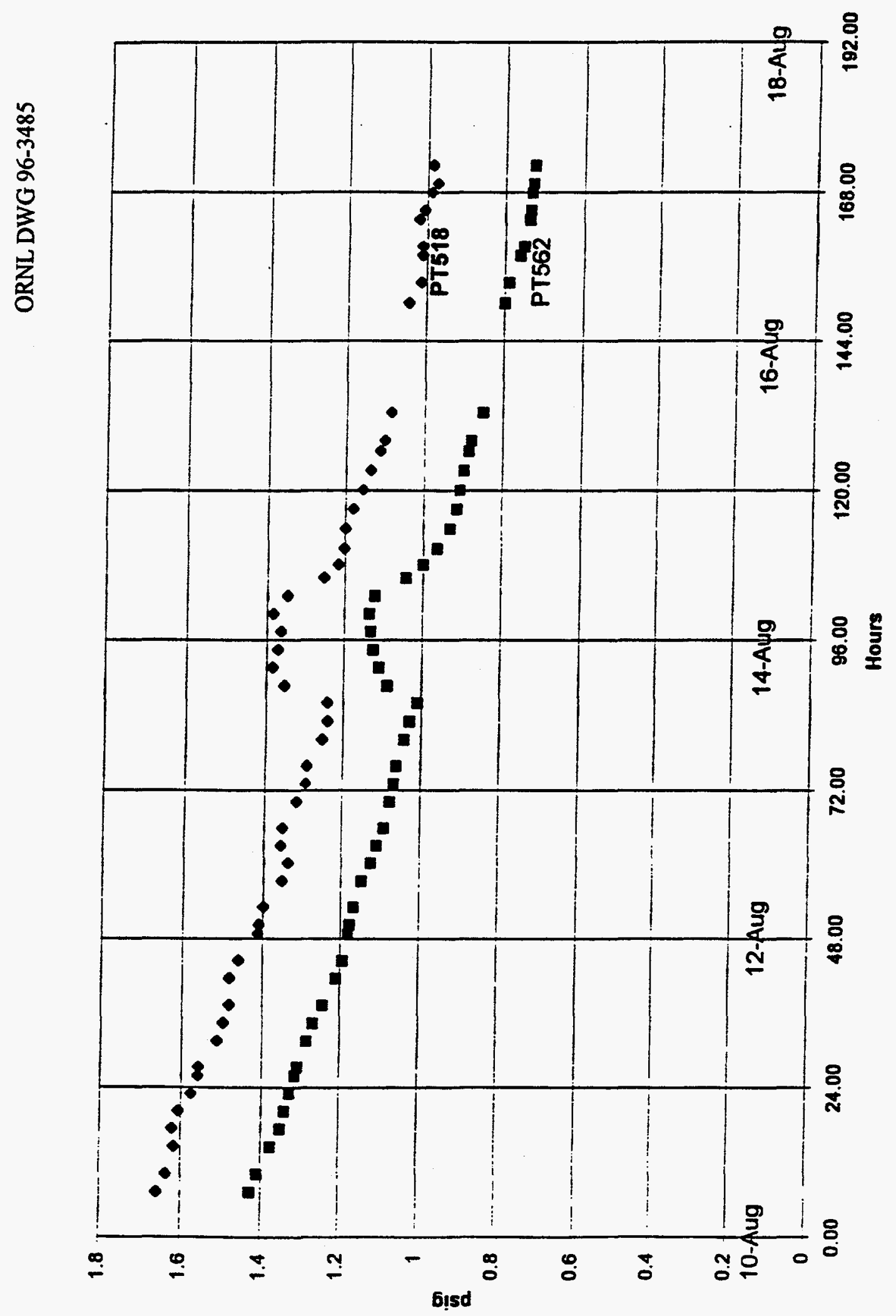

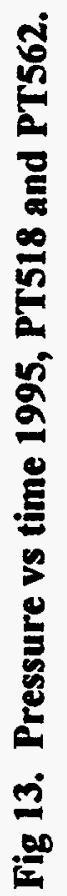




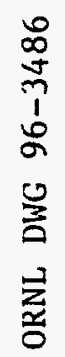

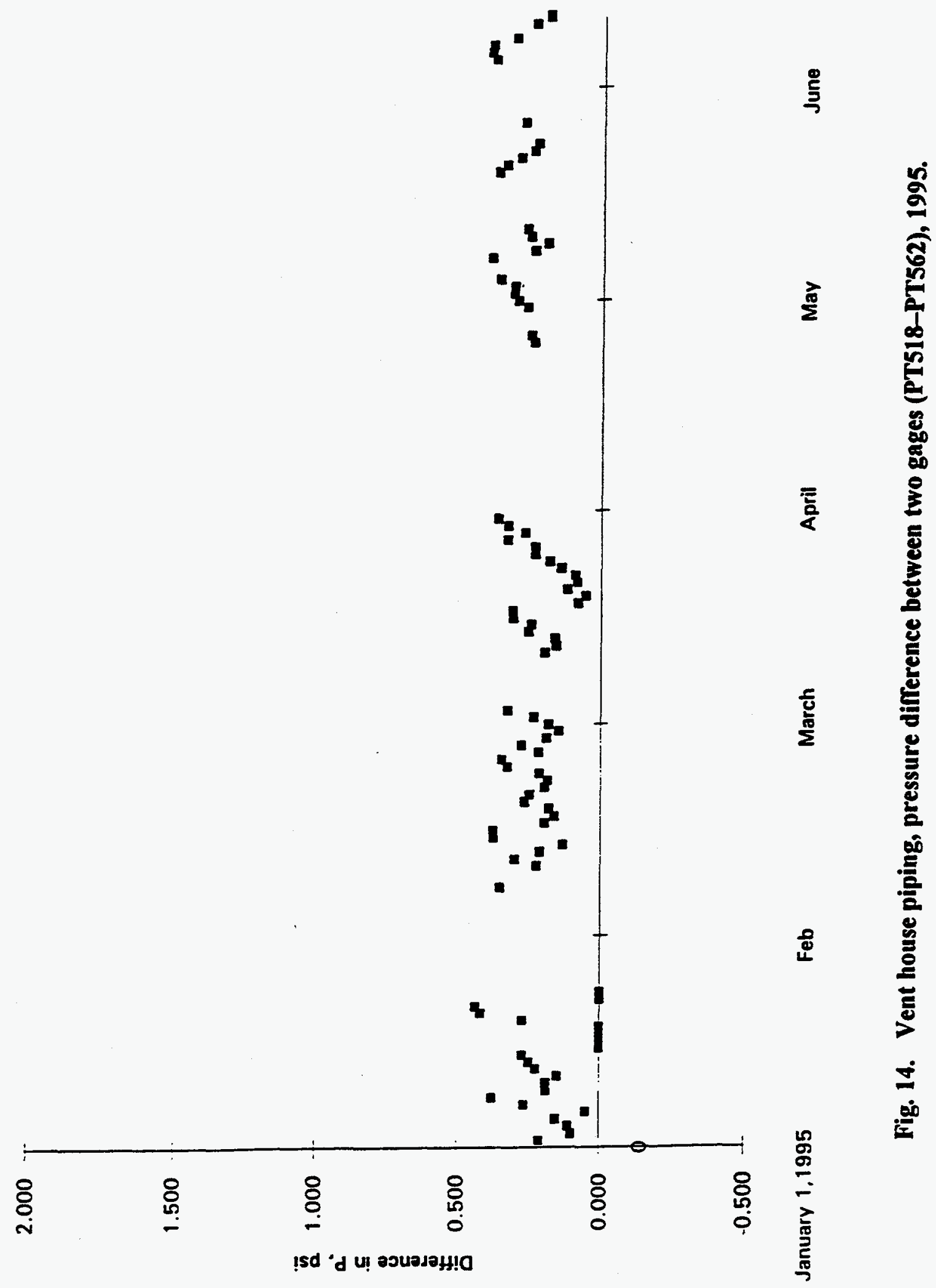




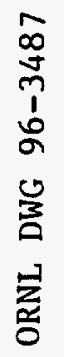

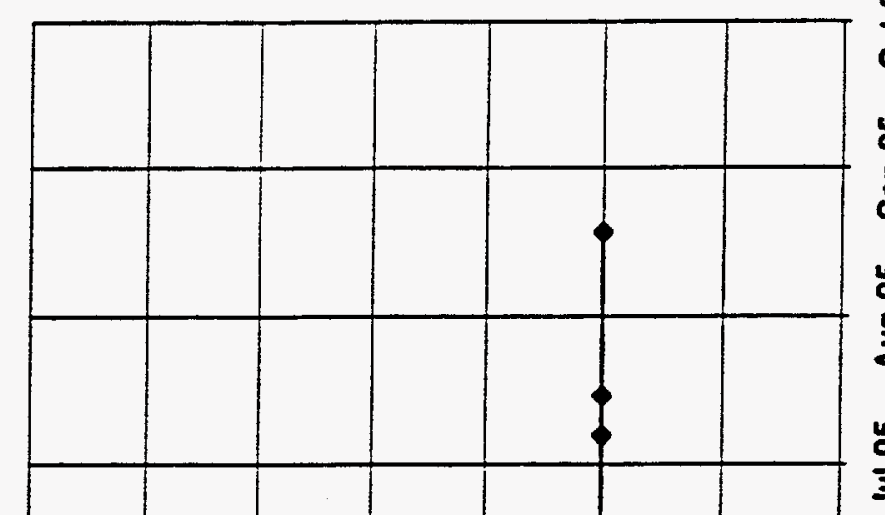

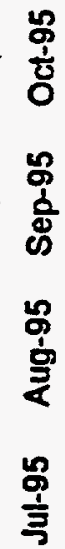

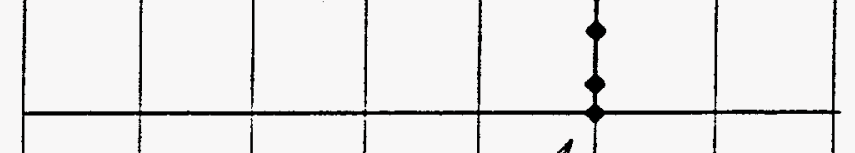

哭

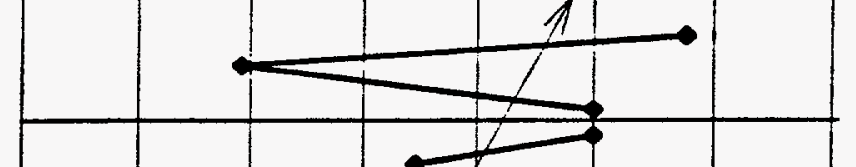

哭

\%

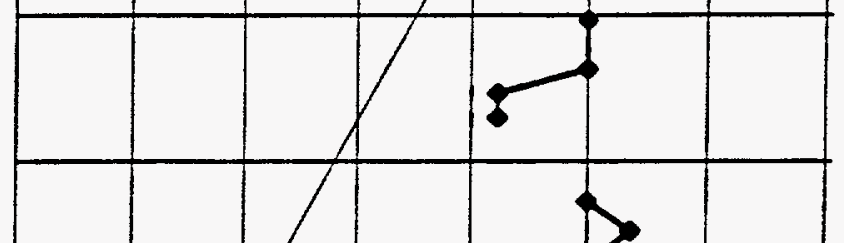

을

น

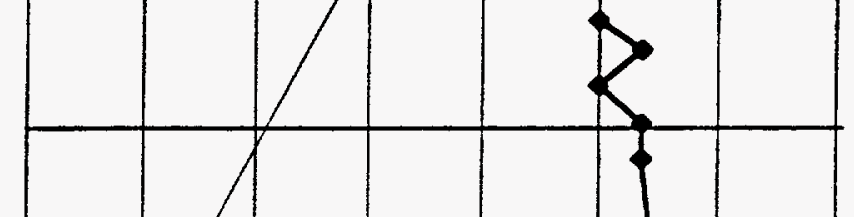

荋

崖

总

올

เே

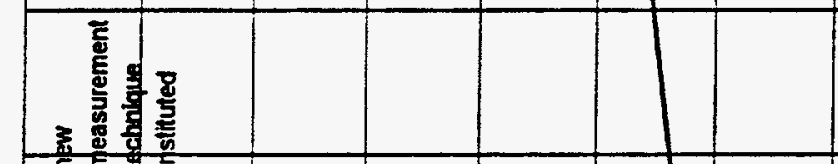

志

is

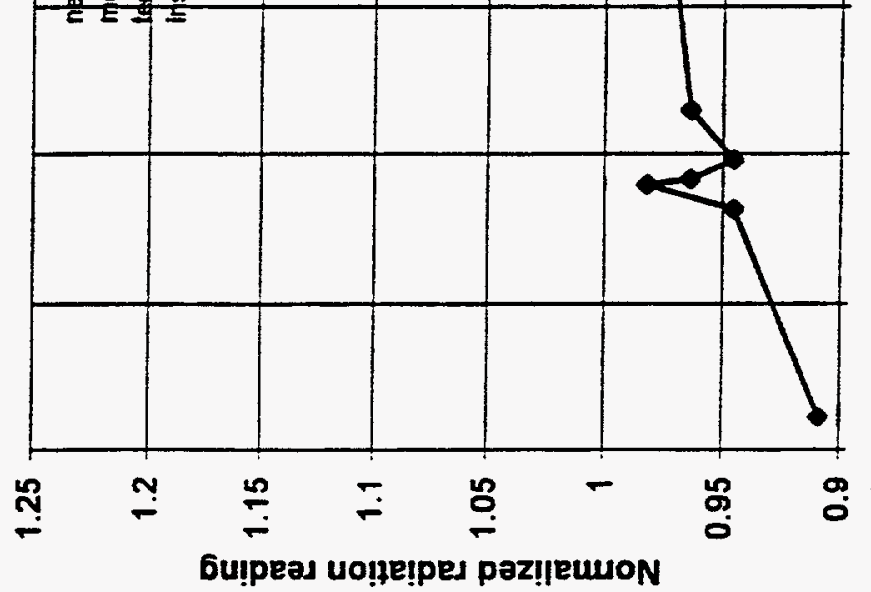

홍

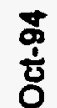

ष

立 
the gamma radiation levels. In June 1995, the position of the detector was standardized to reduce the sources of scatter in the data. It is possible that a long-term rise in the radiation readings is occurring. If this is happening, it could indicate an ingrowth of the ${ }^{208} \mathrm{Tl}$, daughter of ${ }^{232} \mathrm{U}$, or a transport of ${ }^{232} U$ to the general area.

\subsection{CELL PRESSURES AND SUMP LEVELS}

Data of dubious quality are available on the sump levels in the reactor cell, the fuel salt storage cell, the equipment storage cell, the waste tank cell, and the pump room. The gages measure in inches of water and never exceed 1 in. of water at any time. Certain gages vary sinusoidally with the month of the year as shown in Fig. 16, which is a plot of the equipment storage cell sump level, LE-SC, point 18, vs time in months. The variations in other gages appear essentially random, as seen in Fig. 17, which shows the spare cell sump level, LE-TC, point 17. It should be noted that the curve in Fig. 16 is about $180^{\circ}$ out of phase with that of Fig. 5.

The sinusoidal variation has been attributed to the variation in the reference density of air over the period of a year. ${ }^{10}$ The sump levels are based on a difference in pressures between two points, one of which depends on the ventilation vacuum pressure which, in turn, varies with the air density. The reactor and drain tank cells are not ventilated. The fuel storage cell and the waste tank cell have consistently shown negative sump levels. This supports the hypothesis of the variation being related to air density because a negative water level has no physical meaning, while it is possible that a differential pressure could become negative. The reactor cell pressure measured by PT-RC-A, (point 21) is shown in Fig. 18 in pounds per square inch gage vs month and follows an annual cycle similar to the drain tank temperatures in Fig. 5.

The pressure variation (in pounds per square inch), varied sinusoidally over a range of approximately 0.5 psig during the course of 1993 . The reactor and drain tank cells were pressuretested at 5 psi through the years, and their leak rate has grown slightly. ${ }^{11}$

\subsection{WATER MONITORING}

Figure 19 indicates the locations of groundwater monitoring wells in the vicinity of the MSRE building in Melton Valley. The data are shown for well 1089 (Fig. 20), located upgradient 
$\infty$
0
1
7
1
$o$
0
0
$\vdots$
$\vdots$
$\vdots$
$\vdots$
$\vdots$
0

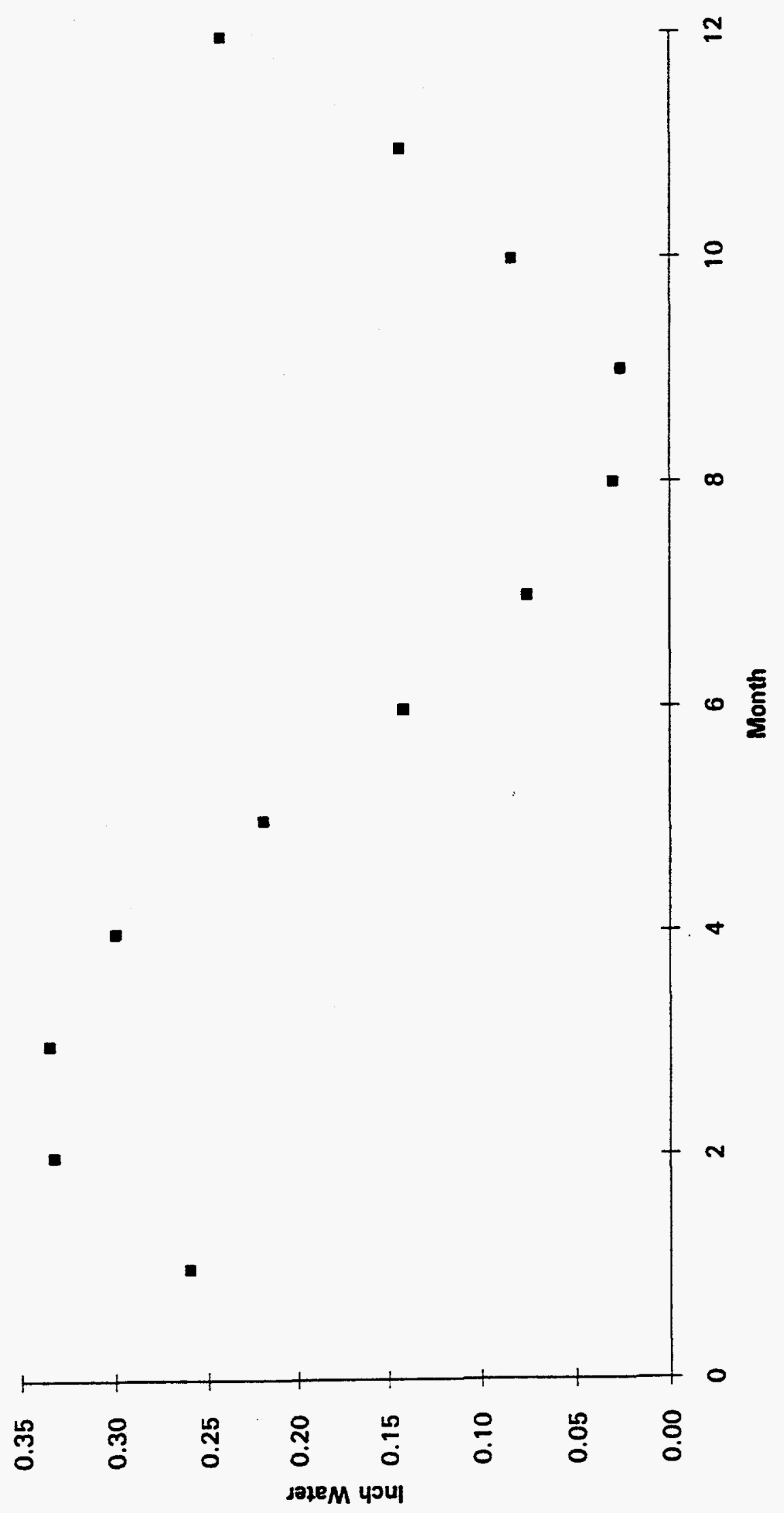




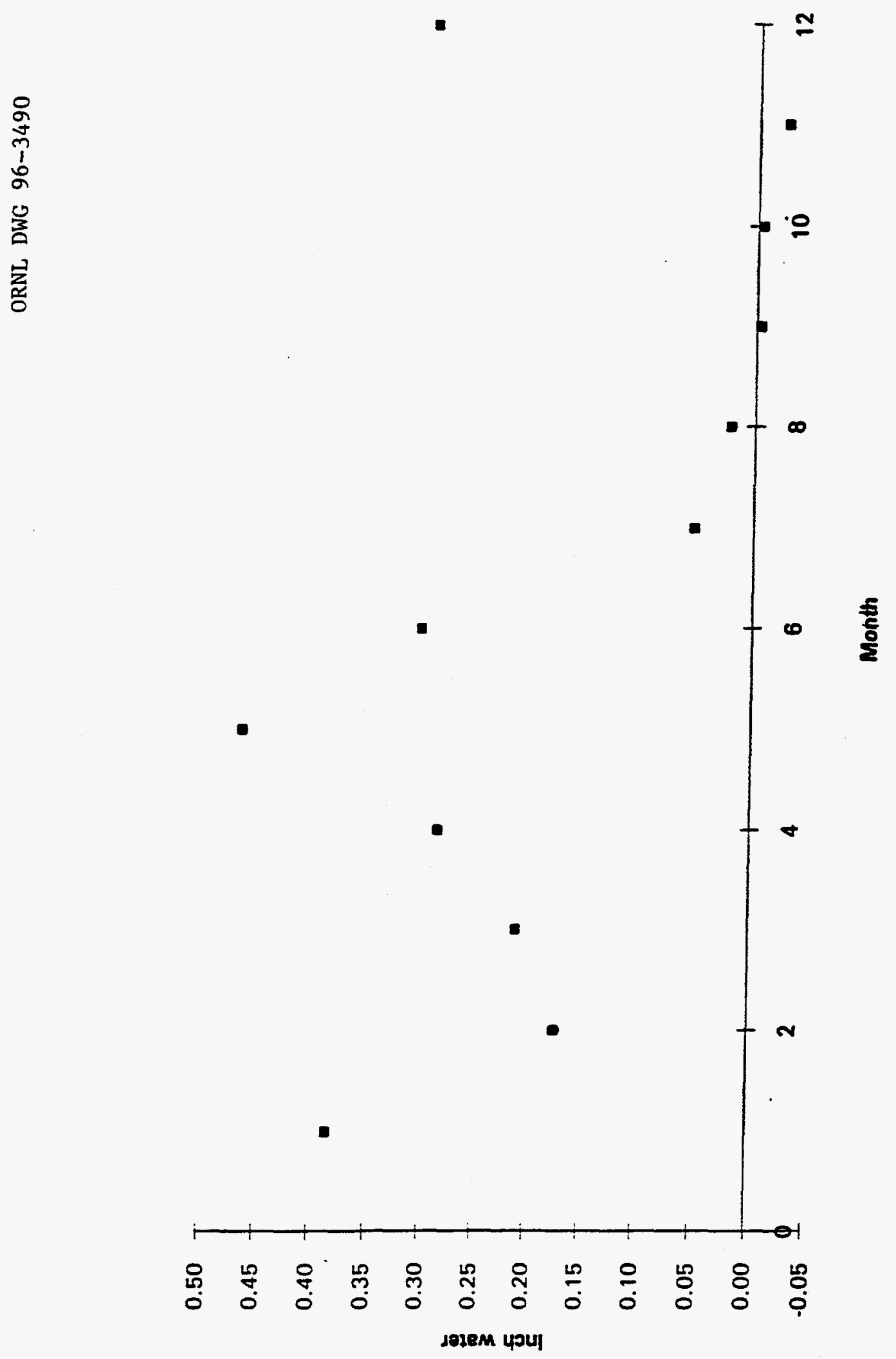

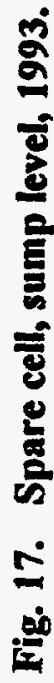




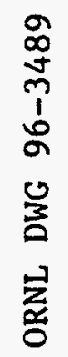

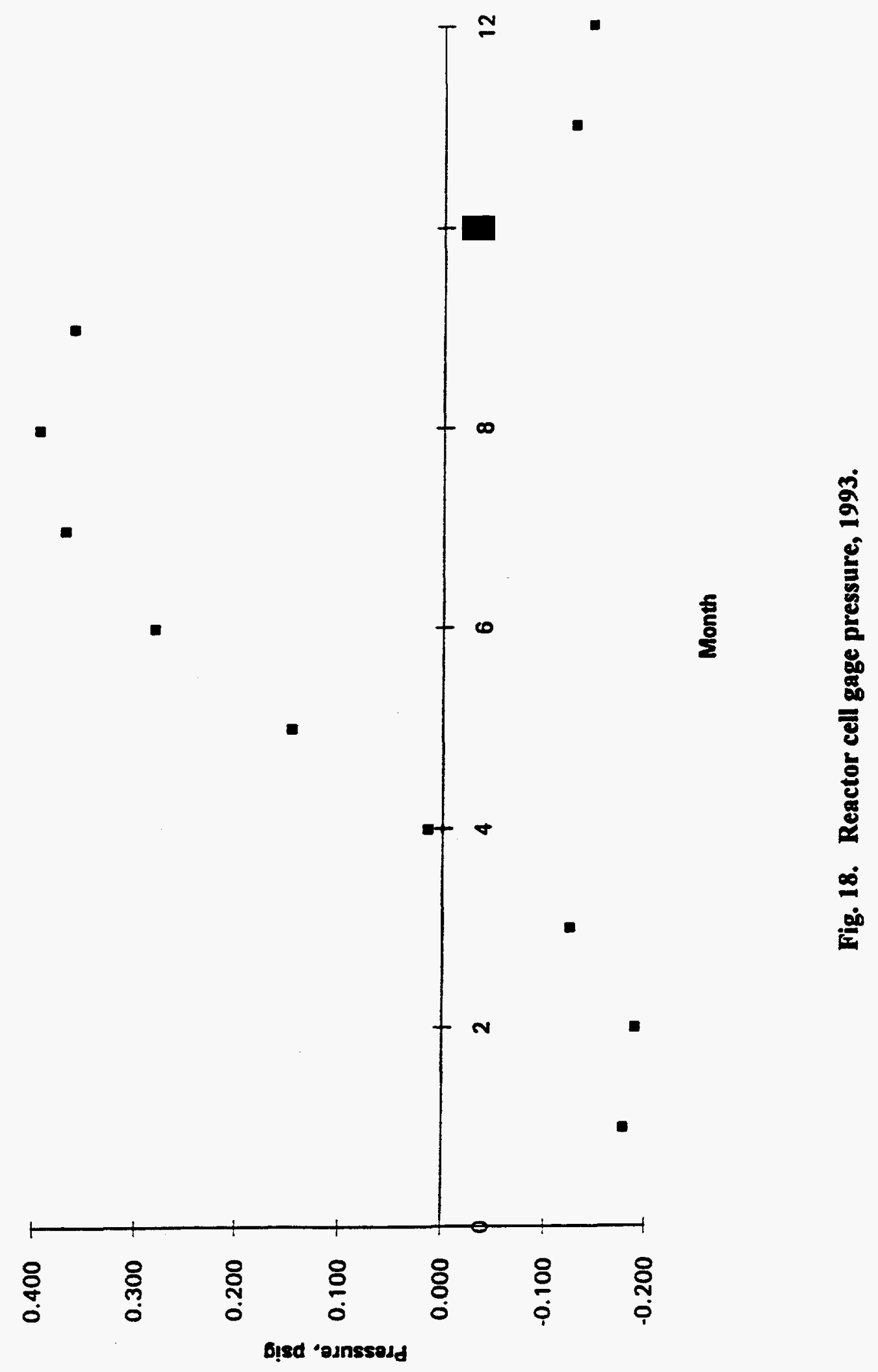


of the MSRE building; wells 1092 and 1093 (Fig. 21) which are nearest and downgradient, from the MSRE building; and well 1151 (Fig. 22), located further downgradient from the MSRE building. Figure 23 shows gross beta readings from well 1151 . Well 1092 is $87 \mathrm{ft}$ deep, 4 in. in diameter, with a screen which rises to a $79 \mathrm{ft}$ depth. Well 1093 is $48 \mathrm{ft}$ deep, 2 in. in diameter, with a screen which rises to a $28 \mathrm{ft}$ depth. Both contain gas displacement and bladder pumps to take samples. Well 1151, constructed in 1989, is at an elevation of $807 \mathrm{ft}$ (above sea level) and is $20.3 \mathrm{ft}$ deep, $2.1 \mathrm{in}$. in diameter, with a screen which rises to a $4 \mathrm{ft}$ depth. Well 1089 is at an elevation of $855 \mathrm{ft}$ and is 2.1 in. in diameter. Well 1092 is at an elevation of $855 \mathrm{ft}$ and is 2.1 in. in diameter. Well 1093 is at an elevation of $840 \mathrm{ft}$ and $2.1 \mathrm{in}$. in diameter.

Data are shown on the gross alpha and (as indicated) beta contamination found during approximately annual samplings performed since $1991 .^{12}$ Radionuclide water contamination data are sketchy, and most values scarcely fall within the uncertainty in the measurement. Where more than one ordinate value is available, the higher indicates a sample that was not filtered for particulate. For reference, a background residential well sample taken in 1992 from the Oak Ridge residential area contained an average of about $0.08 \mathrm{~Bq} / \mathrm{L}$ of gross alpha contamination. ${ }^{13}$ Although there exist wells with closed and screened casings, the data presented pertain only to wells with screened casings. The general conclusion is that there is no evidence of groundwater alpha contamination escaping from the MSRE during this time period. Activity levels are scarcely above reference background levels.

\subsection{AIR MONITORING}

The MSRE stack contains continuous gamma- beta and separate alpha monitors mounted at a $40 \mathrm{ft}$ height which detect gross amounts of contamination flowing in the stacks. Their outputs are connected to the ORNL Emergency Operations Center. Data are shown for alpha and a combination of beta-gamma during 1992; data of 1993 alpha activity are comparable. More detailed data are available from filters on which isokinetic samples are taken continuously on the emission of a number of isotopes. The filter paper is replaced every 2 weeks, and the composited 


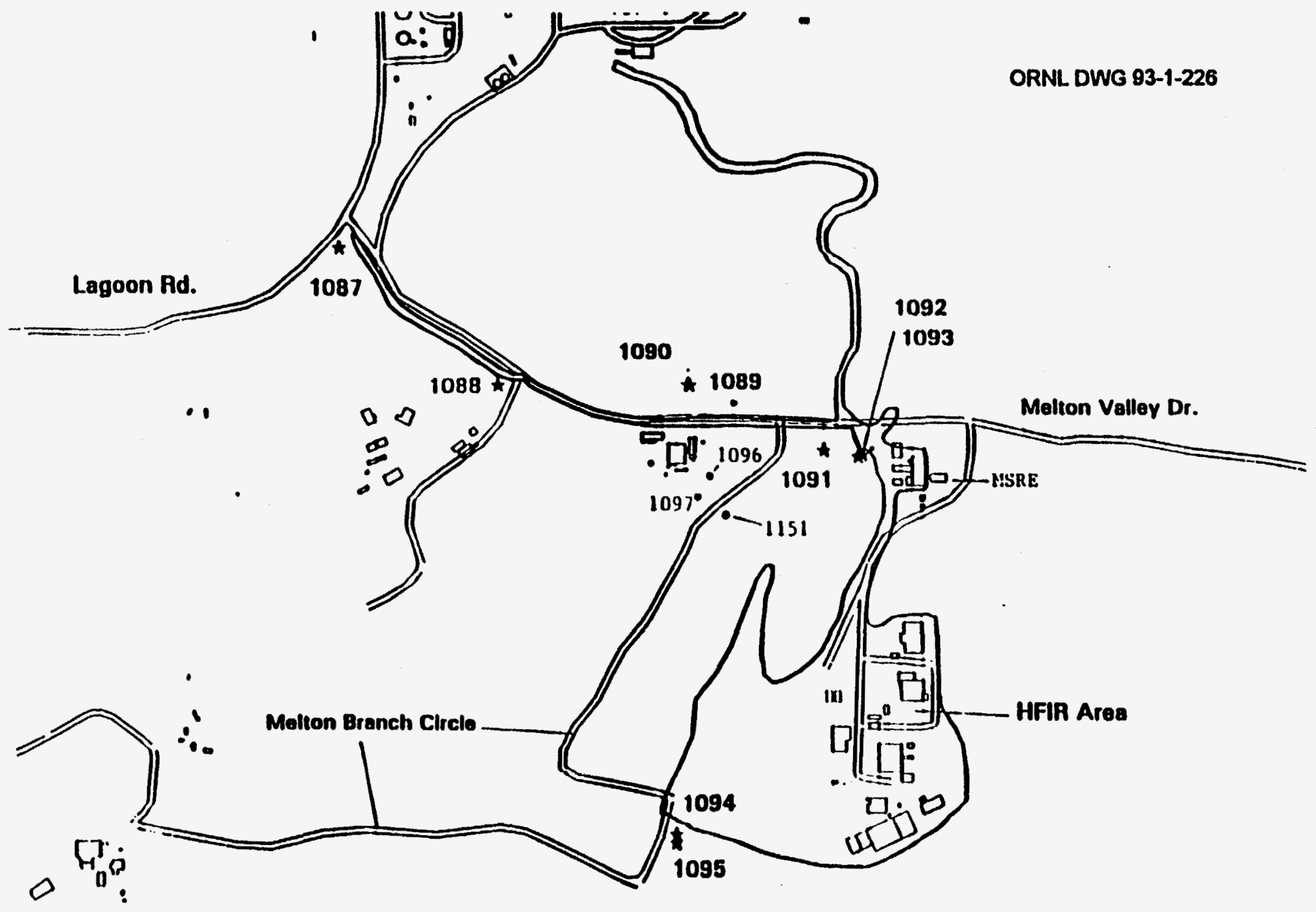

ณ

Fig. 19. Locations of ground water monitoring wells in the vicinity of the MSRE building. 


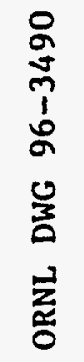

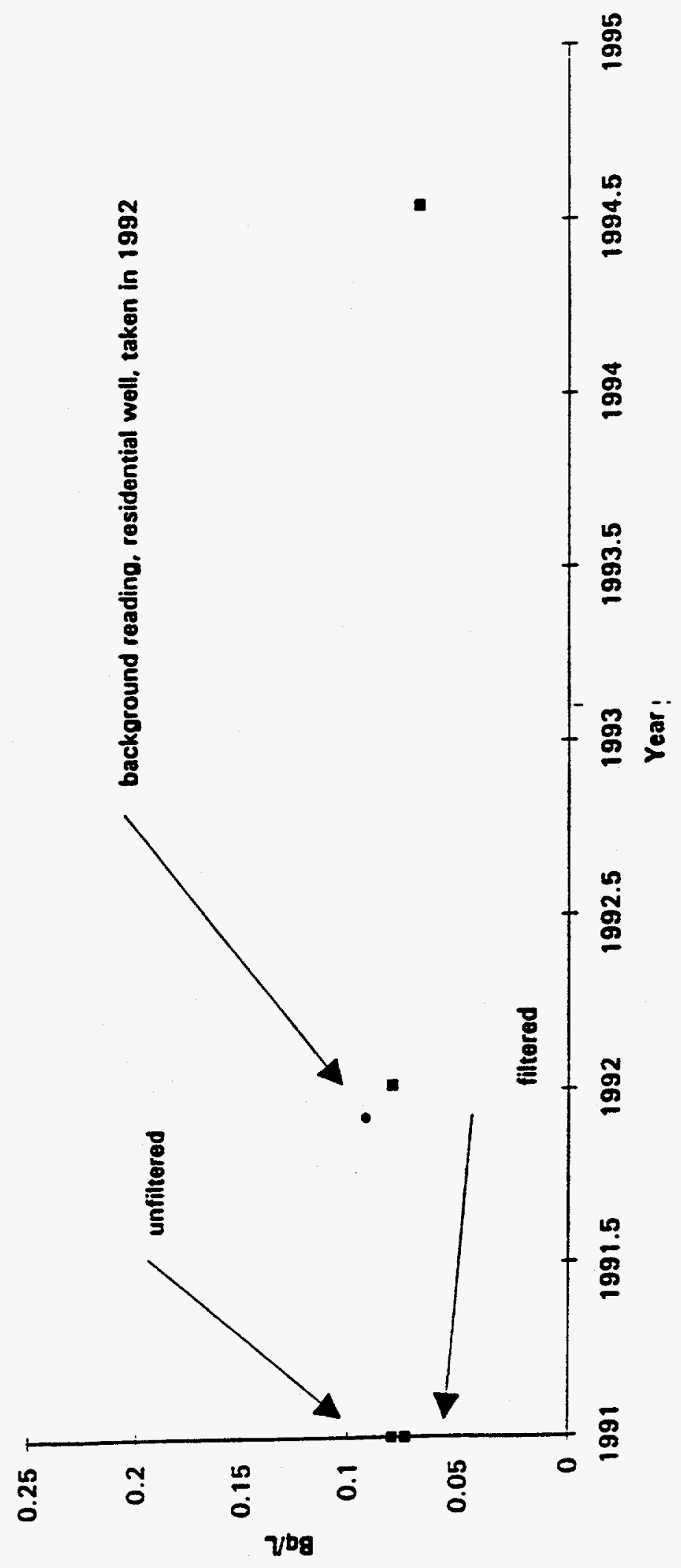


28

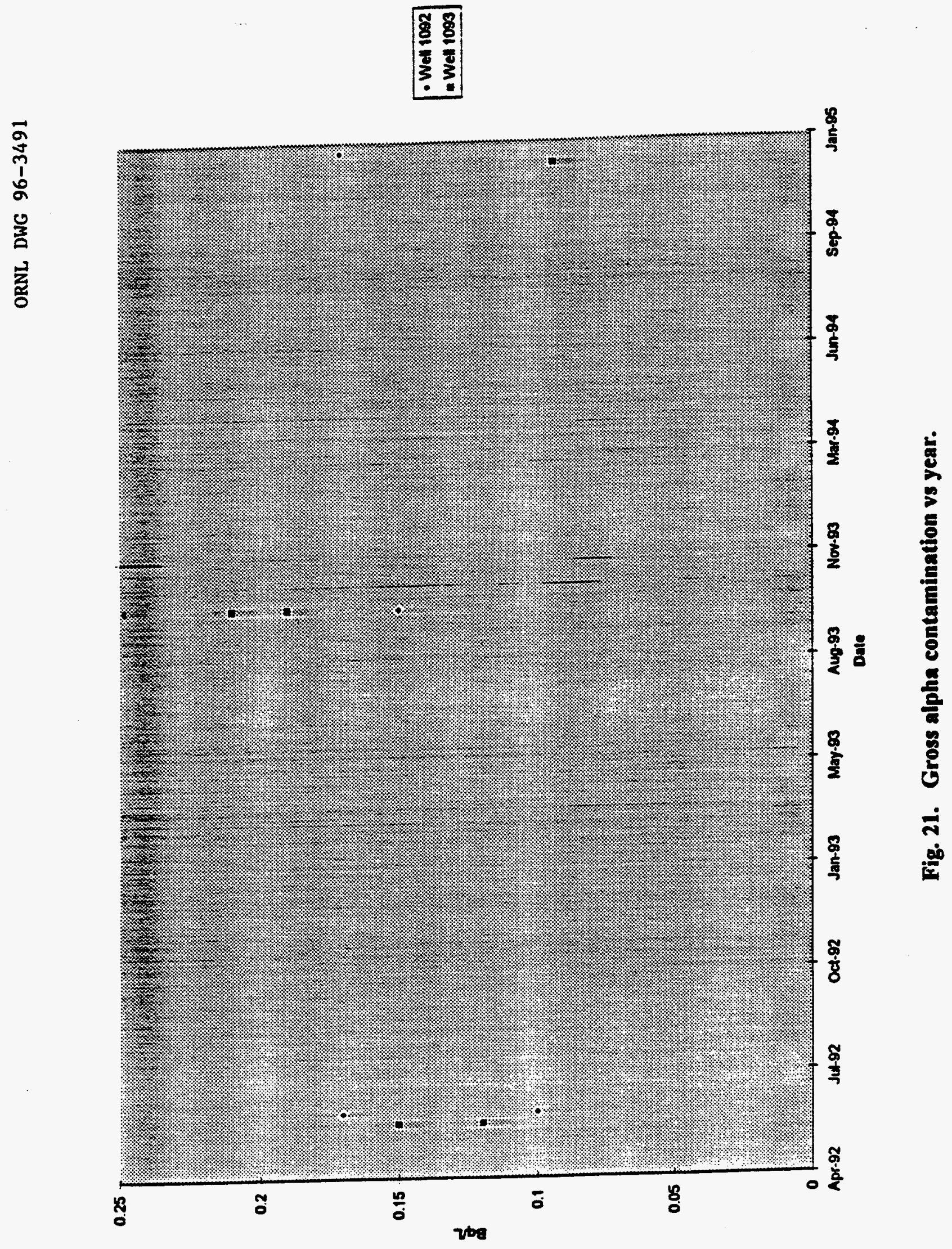




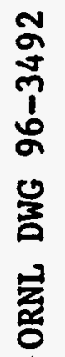

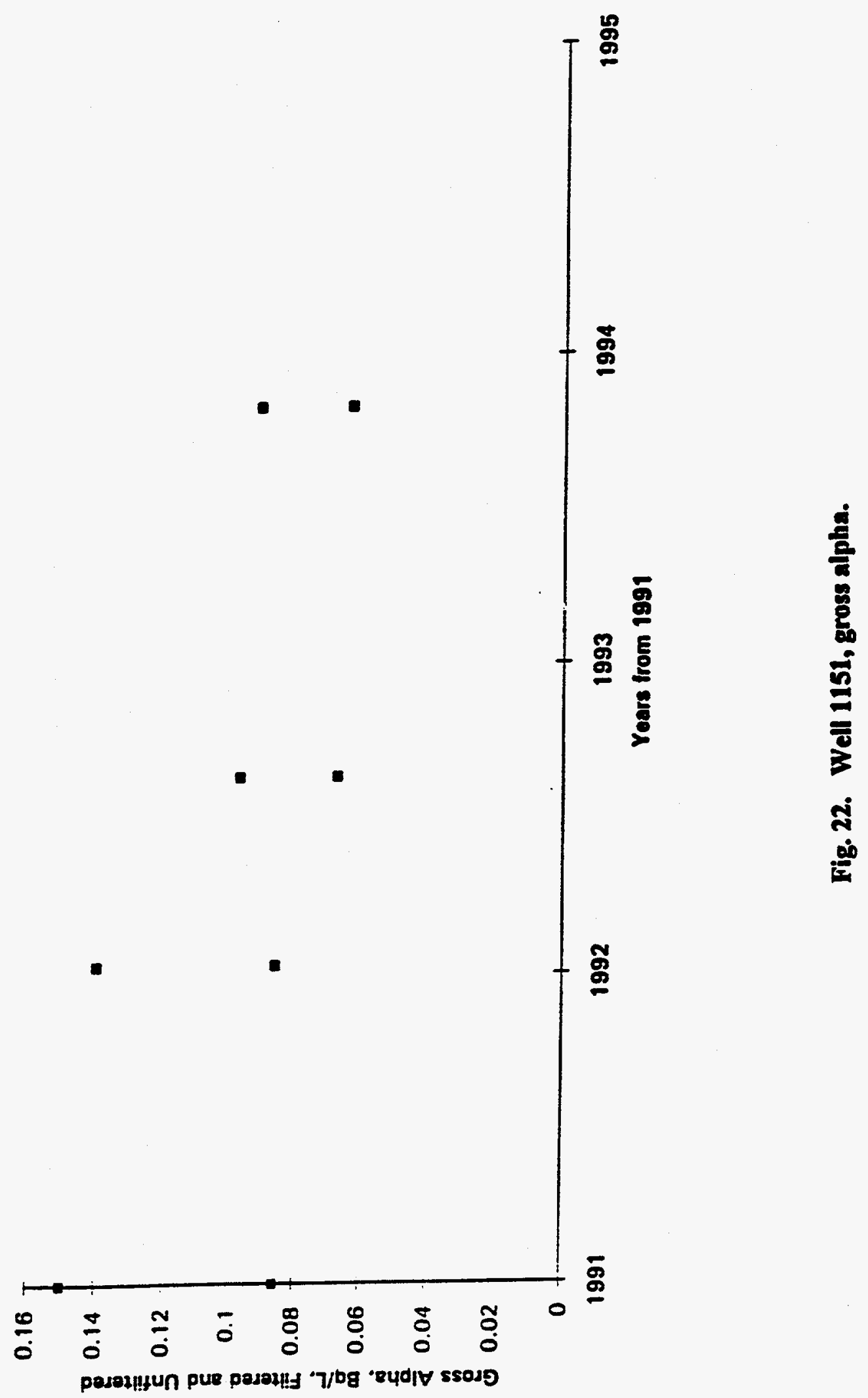




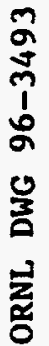

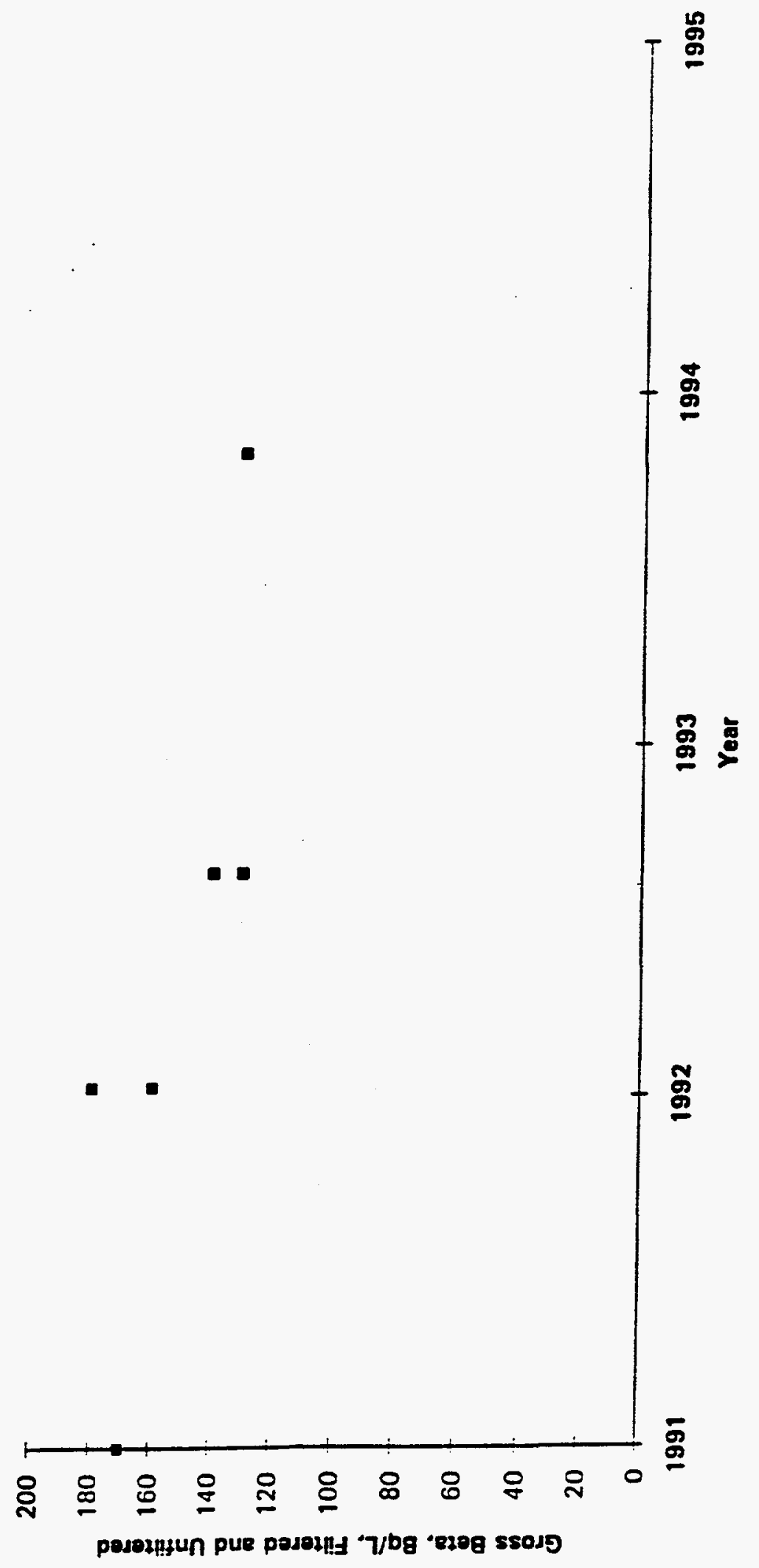


filters are analyzed quarterly. The stack gas flowrate is approximately $10,500 \mathrm{scfm}^{14}$ The results for 1994 represent extrapolations since data were not collected continuously during that period. U.S. Environmental Protection Agency (EPA) Method 1 was used to locate the sampling point, Method 2 to determine the velocity profile within the stack, and Method 3 to determine the gas content. The American National Standards Institute, Inc., (ANSI) Standard N13.1-1969, Guide to Airborne Sampling, and Standard N42.18, Specification for the Continuous Monitoring of and Performance of Onsite Instrumentation, were followed. The data are plotted in Fig. 24, but they are too sparse at present from which to draw conclusions. The data from 1994 are available only for the first and fourth quarters since historically this stack has shown low emissions and was not sampled continuously. Data for 1995 are incomplete and the reported data do not include the results of radionuclide analysis of particulate matter which may have collected in the stack gas probes. All data are based on the material collected in filters which are removed every 2 weeks from the stack and analyzed for gamma emitting nuclides. The filters are then combined and analyzed radiochemically for alpha/beta emitting nuclides quarterly.

\subsection{AIRBORNE SURVEY}

Figures 25 and 26 display contour maps of man-made gross count rates from 1987 and 1992, of the Oak Ridge Reservation and the X-10 site, respectively, taken from EG\&G/EM Remote Sensing Laboratory, reports EGG-10617-1223 and 1123, An Aerial Radiological Survey of the Oak Ridge Reservation. ${ }^{15,16}$ The measurements were made using a NaI(Tl) gamma ray detector mounted on a helicopter. These count rates are adjusted to reflect radioactivity from man-made isotopes only and therefore to correct for variations in natural background activity from minerals. The data has an accuracy of $\pm 15 \%$. It will be observed that the areas near the MSRE site (not shown to the same scale in the two maps) are within the contours A and B. These contours refer to gross counts per second in the range of less than 1000 and between 1000 and 3200 , respectively, and are among the lesser contaminated areas of the reservation in both cases.

\subsection{GAS SAMPLING OF PROCESS PIPING}

Gas sampling and analysis of the process piping were initiated in March 1994 to gain a perspective on the growing radiation readings in parts of Bldg. 7503. The sampling point chosen 

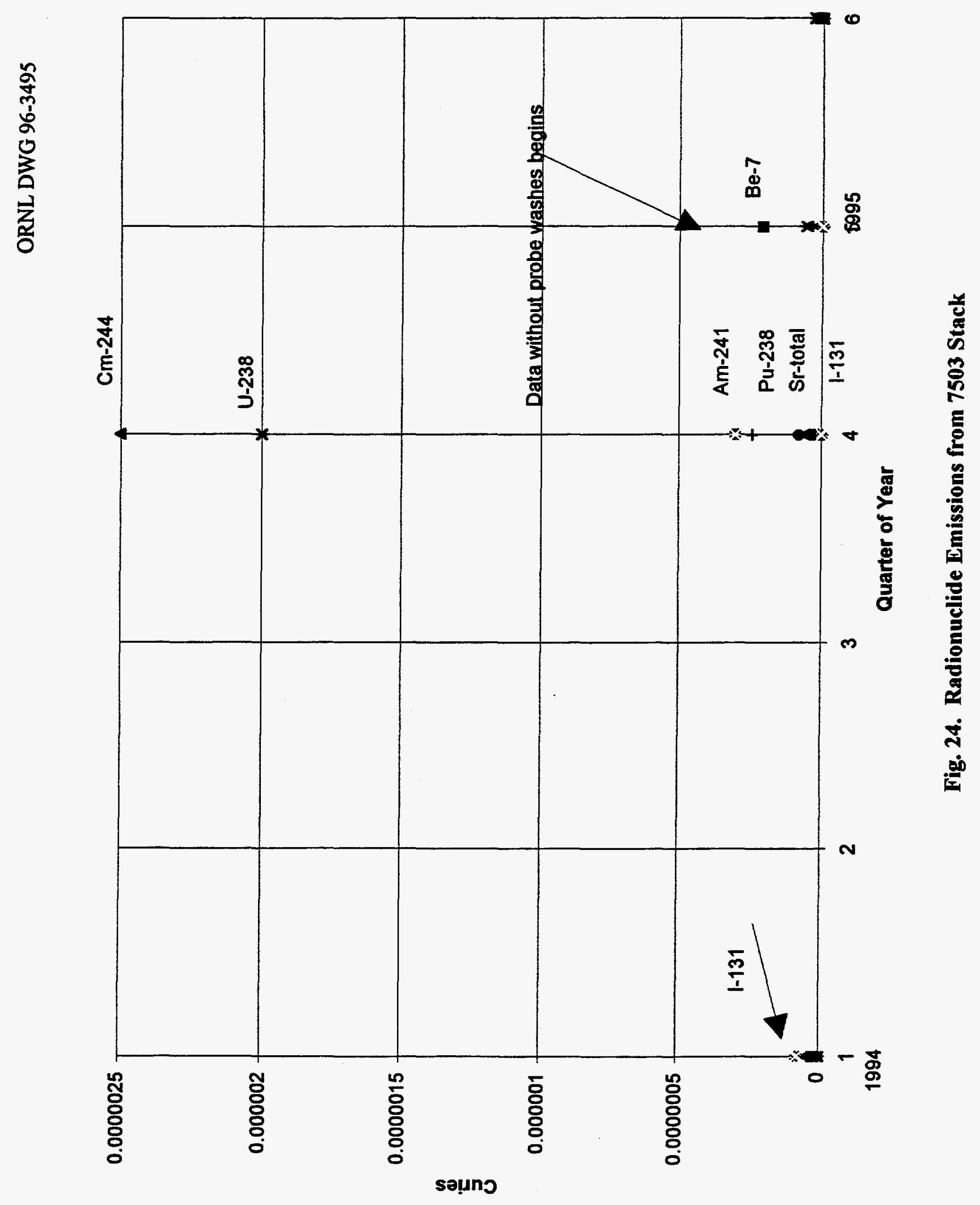


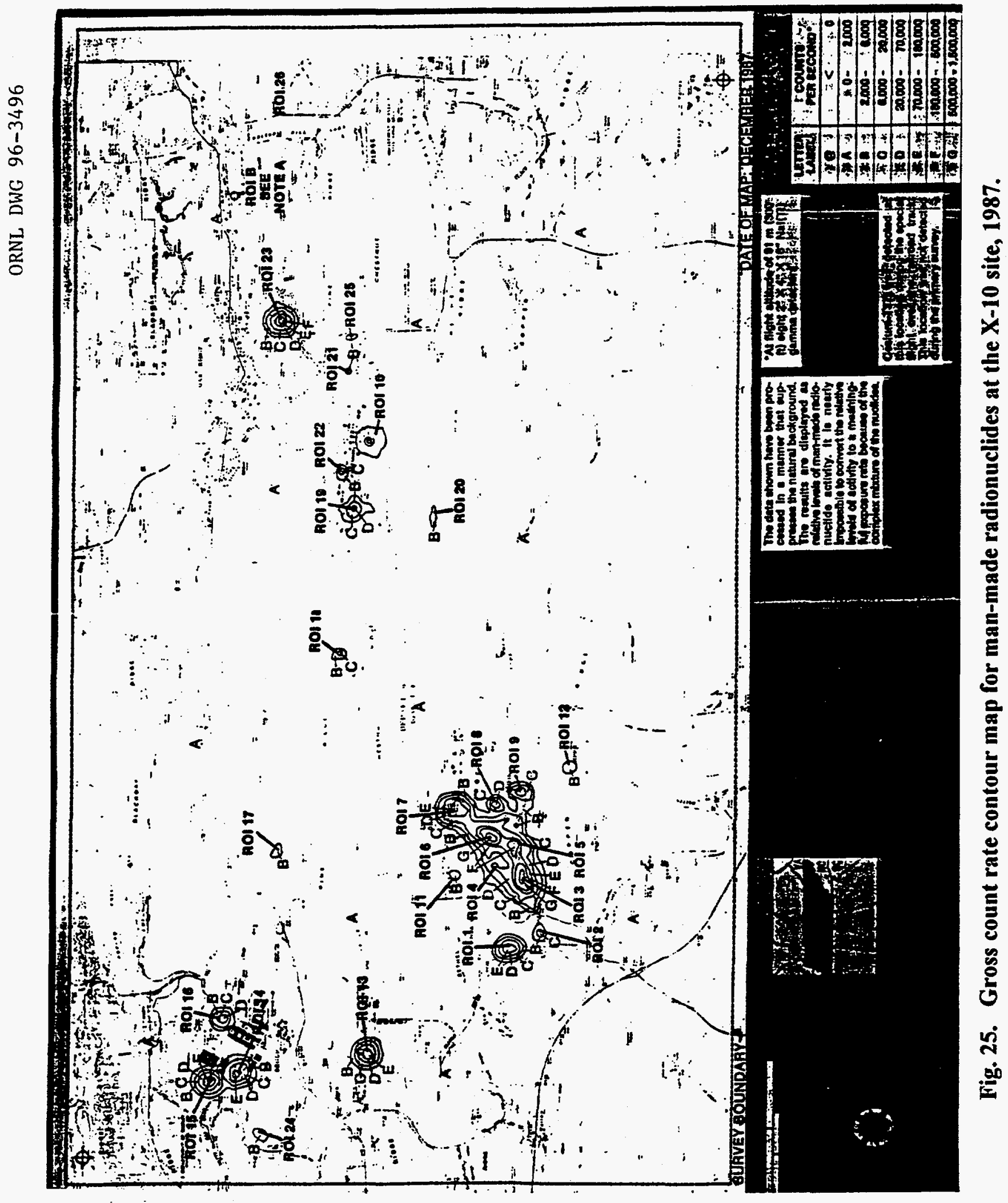



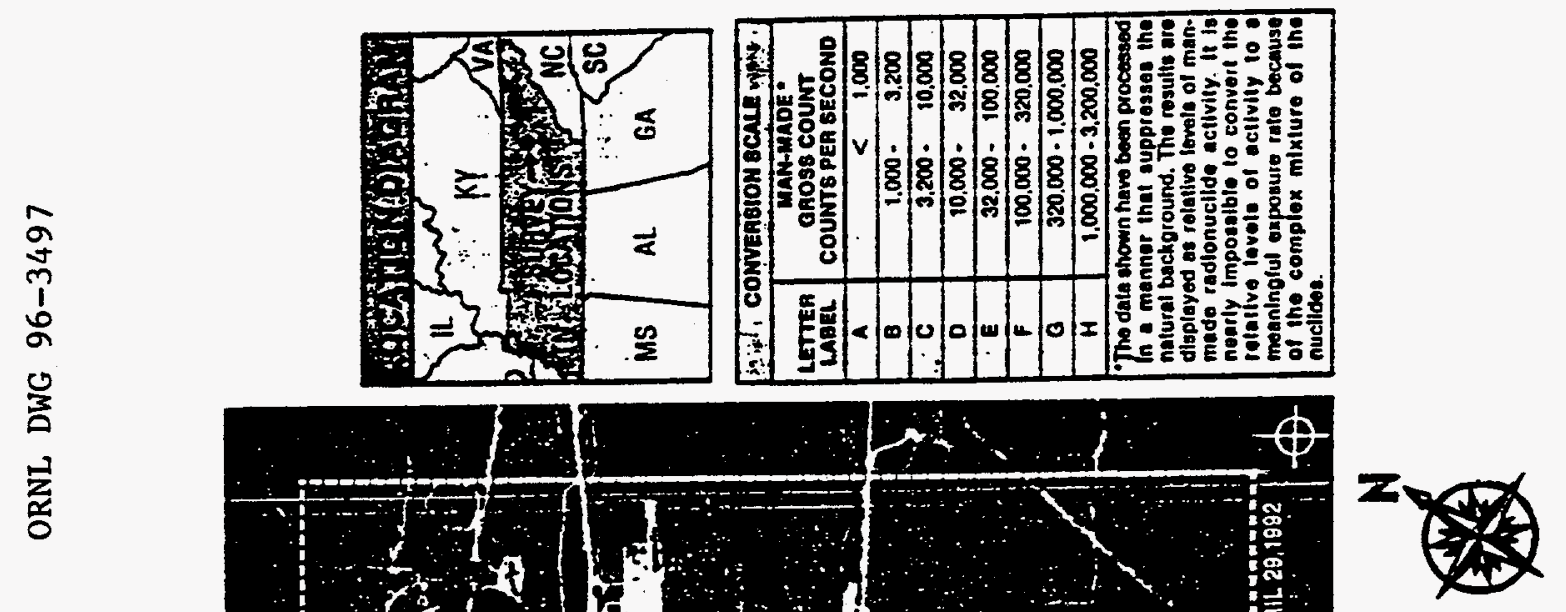

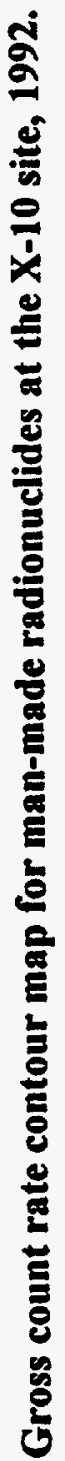

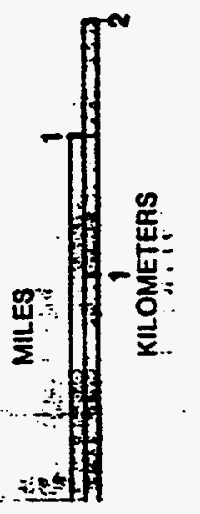

i⿱ 
was located in the vent house because of a comparatively low radiation field, designated sampling point A. It is shown in Fig. 2. Valve HVC533 was opened prior to the sampling and closed afterwards. Two 1-L gas samples were pulled, the second after vacuum pumping the system of $20 \mathrm{~L}$ of gas to analyze the material from a slightly different part of the piping. The line purged quickly (within $5 \mathrm{~min}$ ) so that only a small volume was evacuated. ${ }^{17}$ [A plug, or blank, may exist in line 571, please refer to the drawing in Fig. 2]. The results are shown in Table 2:

Table 2. Results of gas sampling.

\begin{tabular}{|c|c|c|}
\hline & $\begin{array}{l}\text { First sample } \\
\text { (prior to pumping) }\end{array}$ & $\begin{array}{l}\text { Second sample } \\
\text { (20\% pumped) }\end{array}$ \\
\hline $\mathrm{UF}_{6}{ }^{a}$ & $70 \mathrm{~mm} \mathrm{Hg}(0.8 \mathrm{~g} / \mathrm{L})$ & $68 \mathrm{~mm} \mathrm{Hg}(0.8 \mathrm{~g} / \mathrm{L})$ \\
\hline $\mathrm{HF}$ & $1200 \mathrm{ppm}$ & $1000 \mathrm{ppm}$ \\
\hline $\mathrm{MoF}_{6}$ & $10 \mathrm{~mm} \mathrm{Hg}$ & $10 \mathrm{~mm} \mathrm{Hg}$ \\
\hline $\mathrm{CF}_{4}$ & $5 \mathrm{~mm} \mathrm{Hg}$ & $5 \mathrm{~mm} \mathrm{Hg}$ \\
\hline $\mathrm{F}_{2}$ & $\bar{b}$ & $350 \mathrm{~mm} \mathrm{Hg}$ \\
\hline $\mathrm{He}, \mathrm{Ar}, \mathrm{N}_{2}, \mathrm{O}_{2}$ & $305 \mathrm{~mm} \mathrm{Hg}^{\circ}$ & $305 \mathrm{~mm} \mathrm{Hg}^{c}$ \\
\hline
\end{tabular}

${ }^{a} \mathrm{UF}_{6}$ vapor pressure at this temperature $79 \mathrm{~mm} \mathrm{Hg}$.

${ }^{b}$ Not determined analytically but assumed the same as second sample.

${ }^{c}$ Determined by difference from total sample pressure.

A Vacuum Technology Incorporated (VTI) Instrument, quadrupole mass analyzer with a gold blinker, leak-sample inlet system was used to qualitatively detect gases such as $\mathrm{He}, \mathrm{N}_{2}$, and $\mathrm{F}_{2}$. An IR spectrometer was used to identify and quantify the $\mathrm{UF}_{6}, \mathrm{MoF}_{6}, \mathrm{CF}_{4}, \mathrm{HF}$, and some trace components. 



\section{CONCLUSION}

No evidence could be found of the escape of significant contamination from the MSRE in airborne or waterborne emissions data. Water monitoring wells near the MSRE site have shown activity levels lower than those other nearby wells at ORNL. Data on the pressure in piping which were originally connected to the fuel drain tanks indicate that a gradual rise in pressure occurred from February until early August 1995. This pressure appears to have reached a peak of 2 psig in August 1995 as compared to 1 psig in October 1994 and 0 psig in previous years. After August 1994, a comparatively rapid decline took place, possibly because of the spontaneous opening of a check valve set. No stack activity increase was detected in association with this pressure loss. Drain tank cell temperature data have not deviated more than about $10^{\circ} \mathrm{F}$ from their mean since the tank annealing was discontinued in 1989. The fuel drain tank temperatures vary sinusoidally in an annual cycle, with a slight phase lag from the warmest months. The salt temperatures within the tank are higher than the temperatures measured at the outside of the tanks. This difference is very likely due to radioactive decay heat. The charcoal bed cell temperature peaked at a temperature of $90^{\circ} \mathrm{F}$ in August 1995, approximately $5^{\circ}$ higher than the previous year, at which time the $\mathrm{CBC}$ was full of water and less subject to atmospheric thermal changes. The $\mathrm{CBC}$ radiation readings appear to be fairly consistent now that the $\mathrm{CBC}$ is empty of water. The pressure rise in the piping could be explained if the volume of piping exposed to the pressure gage had become reduced since 1994, owing to developing plugs in the lines which have been found to contain condensible $\mathrm{UF}_{6}$; however, this is only a hypothesis at present. The pressure gage PT562 readings follows PT518's readings closely, providing confidence in the trending data, and the differences between the two absolute pressure values have been resolved following recalibration. The $\mathrm{CBC}$ radiation reading appears to be quite consistent now that the $\mathrm{CBC}$ is empty of water. All sumps appear to be dry or to have very low levels of water. In general, continued close scrutiny of the data trends appears to be warranted, especially with respect to understanding the mechanisms of the pressure rises in 1994 and 1995. 



\section{REFERENCES}

1. T. Morelock, Oak Ridge National Laboratory, Oak Ridge, Tennessee, personal communication with J. Shor, Oak Ridge National Laboratory, Oak Ridge, Tennessee, September 18, 1995.

2. Thermocouple: Reference Tables based on the ITS-90, Omega Engineering, Inc., Stamford Conn., 1993.

3. Ronald Sharp, Oak Ridge National Laboratory, Oak Ridge, Tennessee, personal communication with J. Shor, Oak Ridge National Laboratory, Oak Ridge, Tennessee.

4. Ron Ashline, Oak Ridge National Laboratory, Oak Ridge, Tennessee, personal communication with J. Shor, Oak Ridge National Laboratory, Oak Ridge, Tennessee.

5. M. Green, Oak Ridge National Laboratory, Oak Ridge, Tennessee, personal communication with J. Shor, Oak Ridge National Laboratory, Oak Ridge, Tennessee, January 23, 1996.

6. T. Morelock, Oak Ridge National Laboratory, Oak Ridge, Tennessee, personal communication with J. Shor, Oak Ridge National Laboratory, Oak Ridge, Tennessee, July 25, 1995.

7. D. Ramey, Oak Ridge National Laboratory, Oak Ridge, Tennessee, personal communication with J. Shor, Oak Ridge National Laboratory, Oak Ridge, Tennessee, August 17, 1995.

8. HSC Chemistry Ver. 2.0, A. Roine, Outokompu Oi Research, Pori, Finland, 1994.

9. J. Francis, Oak Ridge National Laboratory, Oak Ridge, Tennessee, personal communication with J. Shor, Oak Ridge National Laboratory, Oak Ridge, Tennessee, June 15, 1995.

10. L. Pugh, Oak Ridge National Laboratory, Oak Ridge, Tennessee, personal communication with J. T. Shor, Oak Ridge National Laboratory, Oak Ridge, Tennessee, June 19, 1995.

11. Ibid. 
12. Personal communication of Regis Loffman, Oak Ridge National Laboratory, Oak Ridge, Tennessee, and Richard Ketelle, Oak Ridge National Laboratory, Oak Ridge, Tennessee, June 13, 1995.

13. F. L. Kornegay, Oak Ridge Reservation, Oak Ridge National Laboratory, Oak Ridge, Tennessee, Environmental Report for 1992, ES/ESH-31/V1-V2, 1993.

14. L. Hamilton, Oak Ridge National Laboratory, Oak Ridge, Tennessee, personal communication with J. T. Shor, Oak Ridge National Laboratory, Oak Ridge, Tennessee, September 28, 1995.

15. R. G. Mauer, EG\&G/EM Remote Sensing Laboratory, An Aerial Radiological Survey of the Oak Ridge Reservation and Surrounding Area. EGG-10617-1123, UC-702, 1992.

16. R.G. Mauer, EG\&G/EM Remote Sensing Laboratory, An Aerial Radiological Survey of the Oak Ridge Reservation and Surrounding Area. EGG-10617-1229, UC-702, 1993.

17. D. Ramey, Oak Ridge National Laboratory, Oak Ridge, Tennessee, with J. T. Shor, Oak Ridge National Laboratory, Oak Ridge, Tennessee, September 12, 1995. 
Appendix A.

MISCELLANEOUS ATMOSPHERIC DATA 



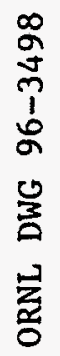

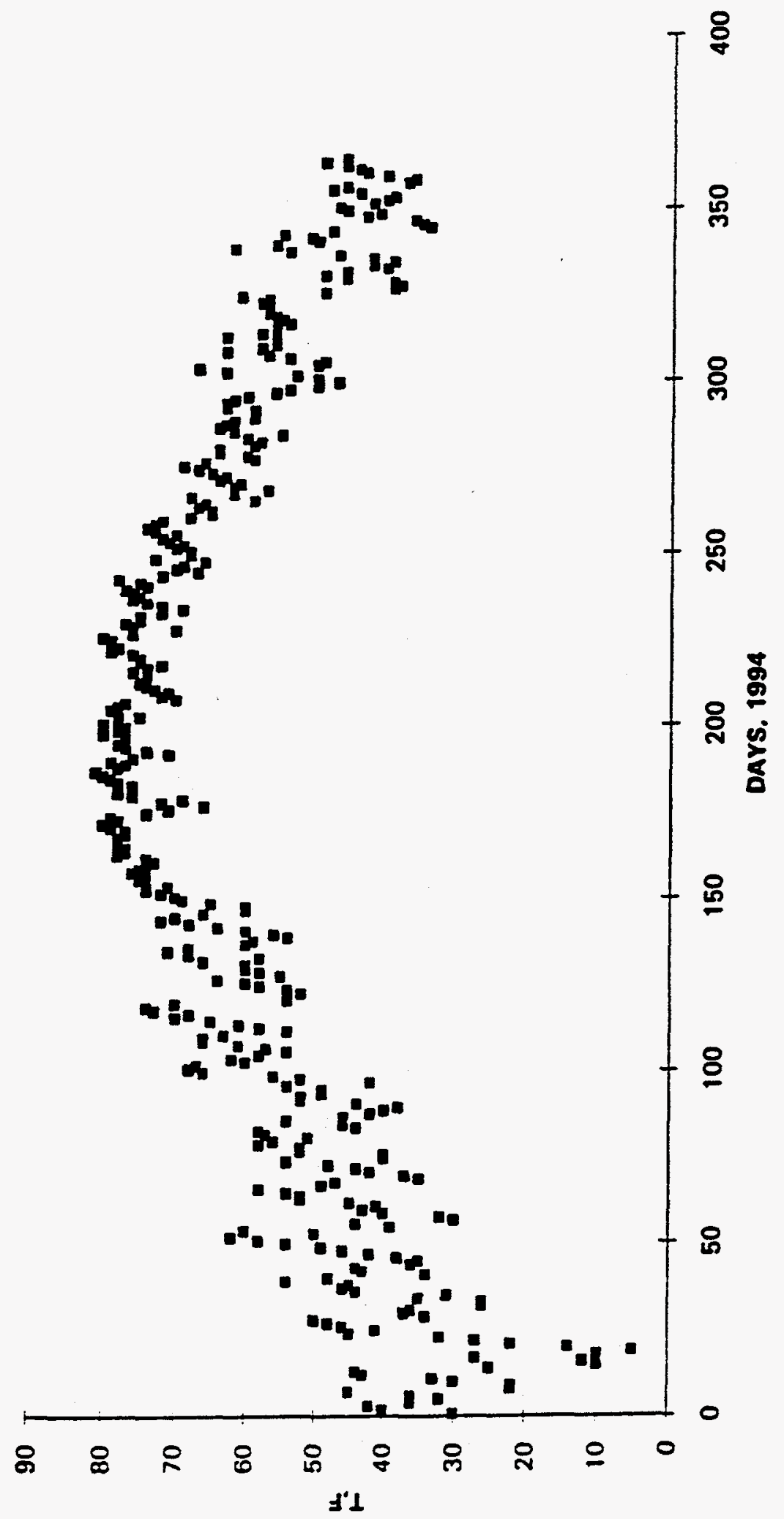


$a$
$a$
m
1
0
0
0
$\vdots$
0
$a$
$\vdots$
0
0

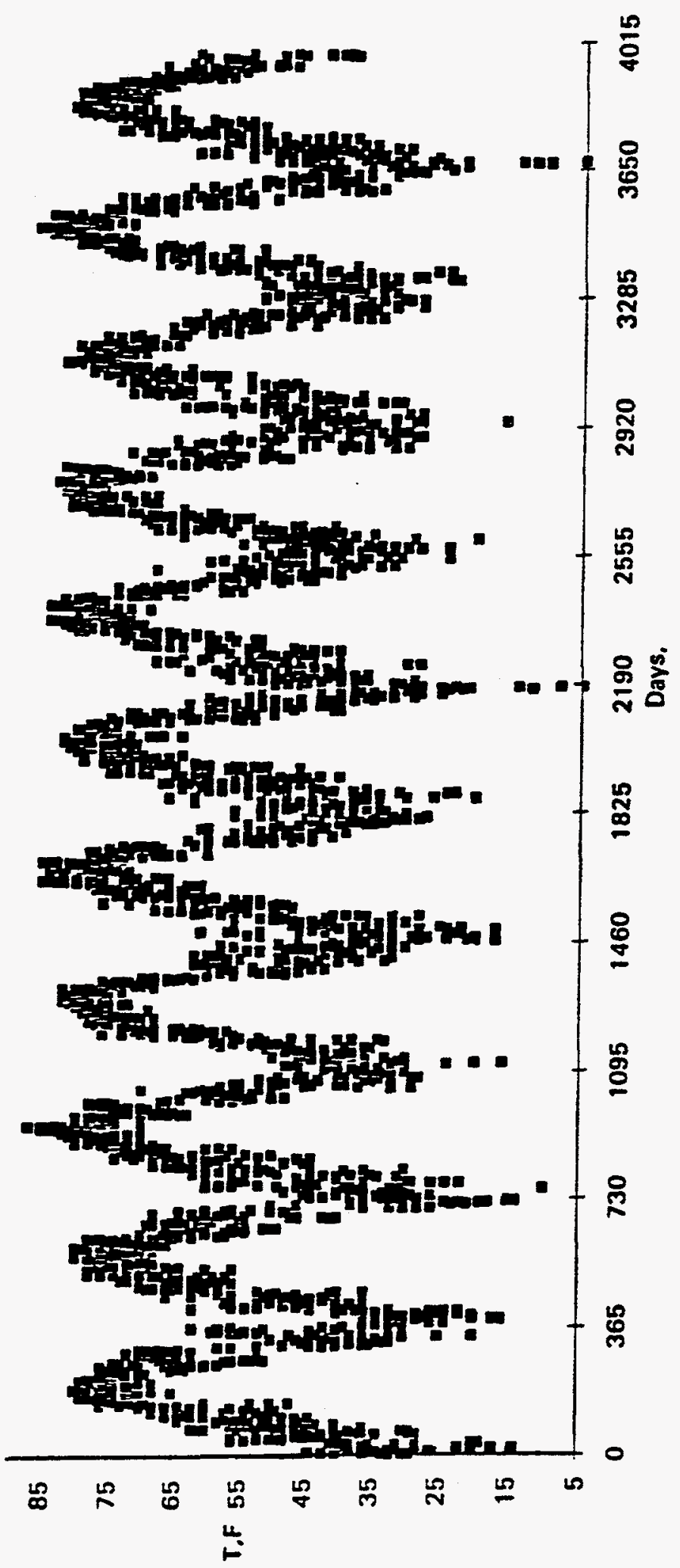




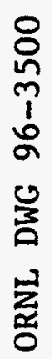

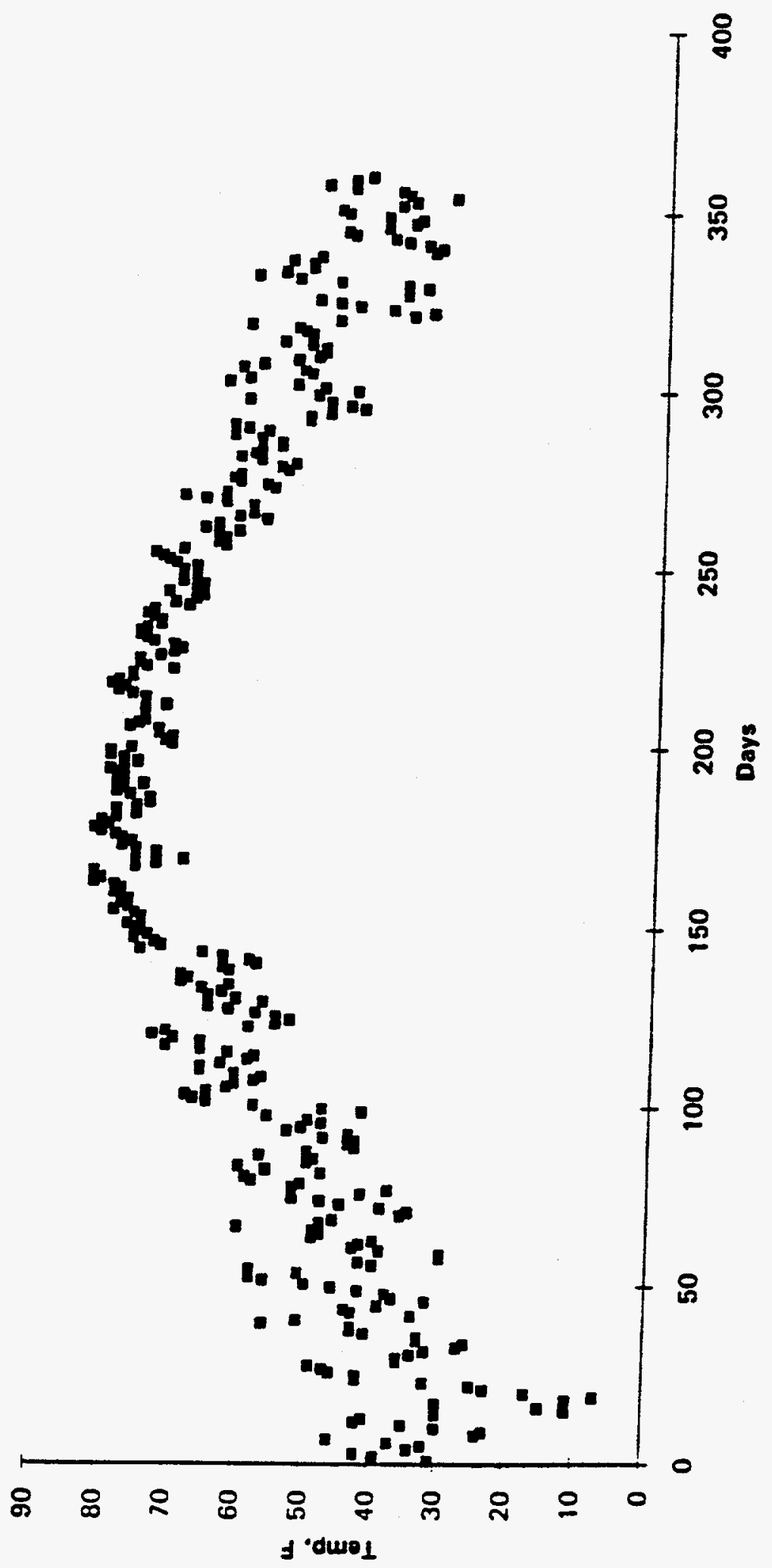

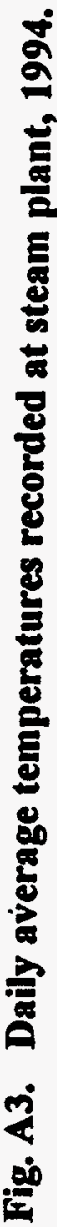



Appendix B.

DRAIN TANK CELL PRESSURE AND TEMPERATURE COMPUTATIONS 



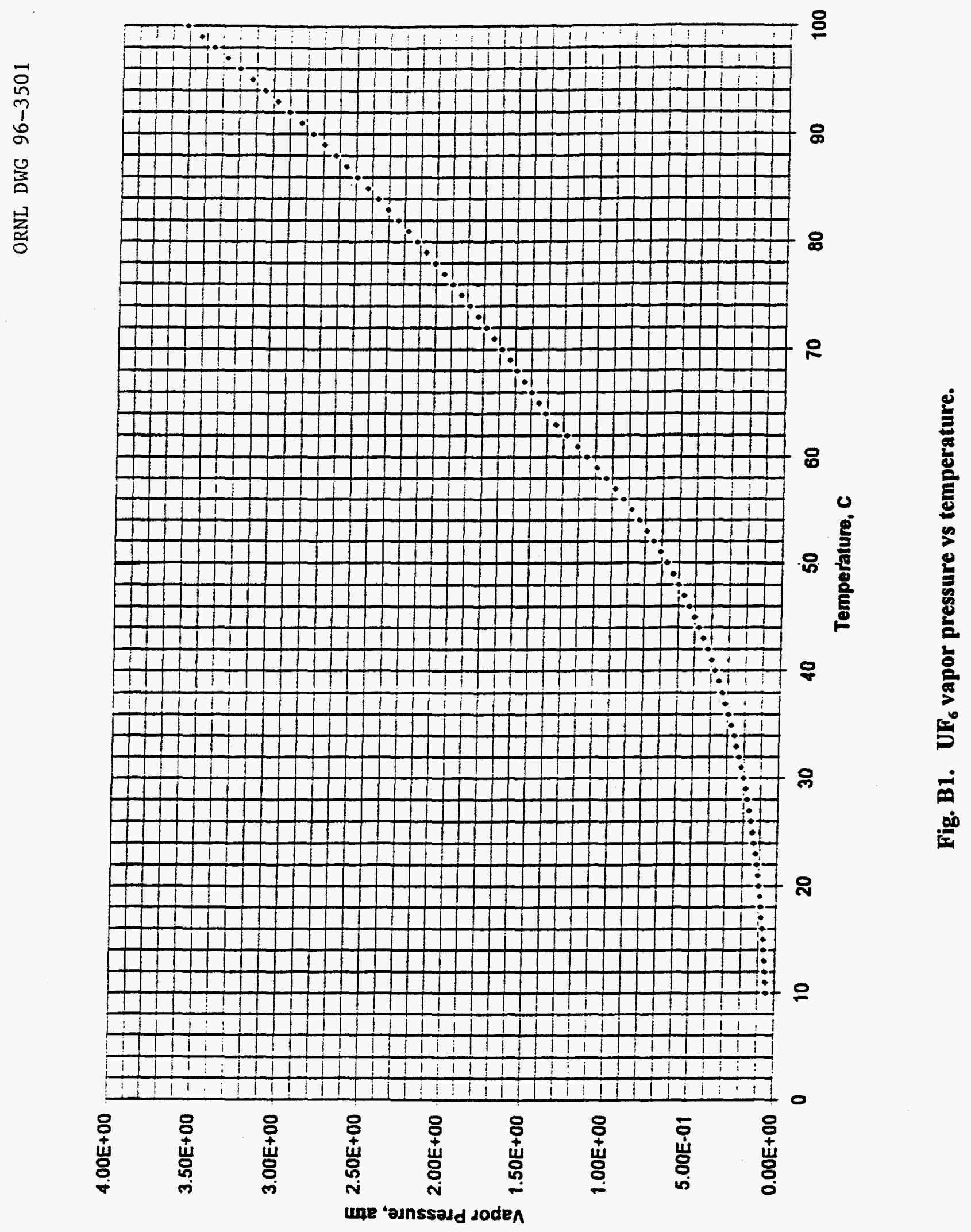





\section{B-5}

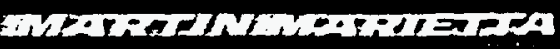

Internal Correspondence

MARTIN MARIETTA ENERGY SYSTEMS, INC.

Date: $\quad$ March 15, 1995

To: $\quad$ J. Rushton

c: $\quad$ J. A. Klein, B. Patton, S. P. N. Singh,

From: $\quad$ J. T. Shor, 105MT, MS-6495, 6-5315 (RC)

Subject: $\quad$ MSRE Drain Tank Cell Temperatures and Pressures Measured at PT518 Pressure Transmitter in Vent House.

PT518 measures the pressure of gas in piping which originates at the 3 MSRE fuel storage tanks located in the drain tank cell, passes through the reactor cell, and terminates in the vent house. This note atrempts to correlate the temperature of this piping with the measured gas pressure and the volatility of $\mathrm{UF}_{6}$ in the line.

Assumptions (general):

1. Volume of gas in piping is fixed at 223 liters.

2. Vent house temperante variations are similar to those of drain tank cell where extensive data are available.

3. All gases are ideal.

4. Only $\mathrm{UF}_{6}$ gas is condensible.

Observations:

1. 1994 pressures of PT518 vary between $\approx 0.9$ and -0.45 psig (monthly averages), between January and August, or 14.3 psia to 15.65 psia $\Delta p=1.35$ psi.

2. Drain tank cell temperatures vary sinusoidally, consistently, and with a period of year.

3. Temperature $(\Delta T)$ variation is between $10^{\circ}$ and $14^{\circ} \mathrm{F}$ typically.

Anaiysis (assume further):

1. Low temperature in piping is $64^{\circ} \mathrm{F}$ or $290.8 \mathrm{~K}$. High temperature in piping is $76^{\circ} \mathrm{F}$ or $297.4 \mathrm{~K}$.

2. Some solid $U_{6}$ is always present in the system and the partial pressure of gaseous $U_{6}$ is represented by the equilibrium vapor pressure of $U_{6}$ at the applicable temperature.

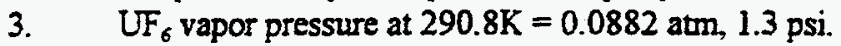

$\mathrm{UF}_{6}$ vapor pressure at $297.4 \mathrm{~K}=0.1390 \mathrm{~atm}, 2.0 \mathrm{psi}$.

$\mathrm{UF}_{6}$ vapor pressure at $299.0 \mathrm{~K}=2.25 \mathrm{psi}$.

$\mathrm{UF}_{6}$ vapor pressure at $300.0 \mathrm{~K}=2.4 \mathrm{psi}$. 


\section{J. Rushton}

\section{Page 2.}

March 15, 1995

\section{Accordingly:}

At $290.8 \mathrm{~K}$, non-condensible gas partial pressure.

$$
\begin{aligned}
& \mathrm{Pi}_{\text {NC }}=14.3-1.3=13 \text { psia, where } P \mathrm{Pi}_{\text {NC }}=\text { partial pressure of noncondensibles. } \\
& \mathrm{N}_{\mathrm{NC}}=\frac{\mathrm{PV}}{\mathrm{RT}}=\frac{(13)(223)}{(0.0821)(290.8) 14.7} \text {, where } \mathrm{N}=\text { number of moles. }
\end{aligned}
$$

8.26 moles of noncondensible gas

Since $\mathrm{Pi}_{\mathrm{UF} 6}=1.3 \mathrm{psi}$ (its vapor pressure), we have 0.826 moles of $\mathrm{UF}_{6}$ gas

$\mathrm{Pi}_{\mathrm{UF6}}=1.3 \mathrm{psi}$

\section{At $297.4 \mathrm{~K}$}

$\mathrm{N}_{N C}$ is unchanged at 8.26 moles since $\mathrm{V}$ is unchanged

$\mathrm{N}_{\text {upe }}$ however is 1.27 moles now owing to additional volatilization

$N_{\text {mat }}=9.53$ moles

This implies a $P_{\text {TOTNL }}=\frac{N R T}{V}=\frac{(9.53) R 297.4}{223}$

$=15.3$ psia

Thus, the calculated $\Delta p$ is equal to $1 p s i$ while the measured $\Delta p$ is equal to $1.3 p s i$.

Consider the situation at $299 \mathrm{~K}$, about $1.5^{\circ} \mathrm{K}$ higher

$\mathrm{Pi}_{\mathrm{UrF}}=2.4 \mathrm{psi}$ or $0.163 \mathrm{~atm}$

$\mathrm{N}_{\mathrm{UF} 6}=1.48$

$\mathrm{N}_{\text {TOTNL }-9.74}$

This implies $P_{\text {TorsL }}=15.76$ psia using the same approach which is 0.11 psi greater than that actually measured. Therefore, an error in temperature measurement of less than $1.5^{\circ} \mathrm{K}$, well within the uncertainty of this analysis, could account for the $\Delta p$ recorded.

Source of $\mathrm{UF}_{6}$ vapor pressure data HSC OutoKompu (BKK 1977) 


\section{B-7}

\section{J. Rushon}

Page 3.

March 15, 1995

If no $\mathrm{UF}_{6}$ is present (i.e. all gas was noncondensible) it would require a temperature rise of $\sim 27^{\circ} \mathrm{C}$ to accoumt for the rise in pressure observed.

A scatter plot of PT518 pressure vs average monthly temperature in the drain tank cell has an $R^{2}$ of 0.86 , see attached figure.

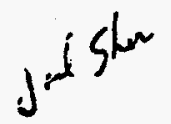

JSns

Attachionent 


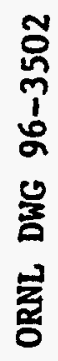

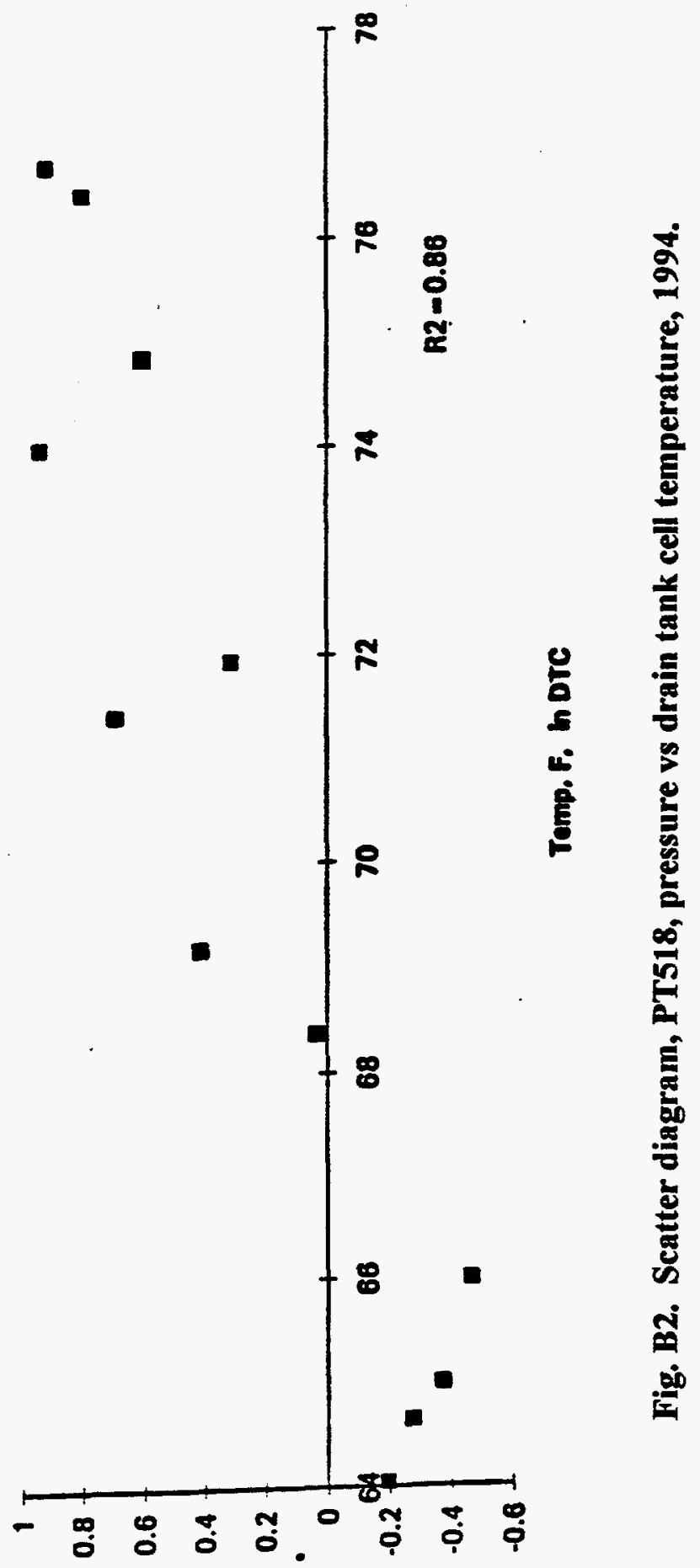

8yed 'ojnseald 


\section{INTERNAL DISTRIBUTION}

1. J. M. Begovich

2. S. N. Burman

3. R. M. Canon

4. L. E. Creech

5. A. G. Croff

6. G. D. Del Cul

7 J. R. Devore

8. M. D. Easton

9. R. L. Faulkner

10. M. K. Ford

11. J. E. Francis

12. M. A. Green

13. E. M. Hodges

14. J. S. Ivey

15. P. S. Johnson

16. J. R. Keiser

17. B. L. Kimmel

18. S. G. Kimmett

19. R. A. Kite

20. M. J. Kreger

21. L. E. McNeese

22. G. T. Mei
23. D. E. Mueller

24. S. H. Park

25. B. D. Patton

26. F. J. Peretz

27. D. W. Ramey

28-29. J. E. Rushton

30. G. W. Sherrill

31. R. M. Szozda

32. P. R. Sanders

33-37. J. T. Shor

38. S. P. Singh

39. L. M. Toth

40. L. D. Trowbridge

41. K. L. Walker

42. D. F. Williams

43. ER Document Management Center

44. Central Research Library

45. Y-12 Technical Library

Document Reference Center

46. ORNL Patent Section

47-48. ORNL Laboratory Records

49. ORNL Laboratory Records RC

\section{EXTERNAL DISTRIBUTION}

50. E. C. Crume, Jr., Pragmatics Inc., 708 S. Illinois Avenue, Suite E105, Oak Ridge, TN 37830.

51. J. R. Engel, 118 E. Morningside Drive, Oak Ridge, TN 37830.

52. M. R. Jugan, Environmental Restoration, Department of Energy, Oak Ridge Operations, P.O. Box 2001, Oak Ridge, TN 37831.

53. K. J. Notz, Henley Point-River Road, Kingston, TN 37763.

54. L. P. Pugh, 2024 Cedar Lane, Kingston, TN 37763.

55-56. Office of Scientific and Technical Information, P.O. Box 62, Oak Ridge, TN 37831. 
